\title{
Investment-Cash Flow Sensitivity Around the Crisis: Are African Firms Different?
}

\author{
Michael Machokoto*, Ngozi Ibeji ${ }^{\dagger}$, Chimwemwe Chipeta ${ }^{\ddagger}$
}

September 15, 2020

Purpose: This paper examines the contentious relationship between investment and cash flow using the 2008-09 credit supply shock as a form of quasi-natural experiment.

Methodology: Panel threshold models with unknown sample separation are estimated for a sample of publicly listed firms from nine African countries over the period 20032012. Using this approach reduces subjective or ex-ante sample splitting bias that is not accounted for in the extant literature.

Findings: We show that investment-cash flow sensitivity is decreasing even during the Global Financial Crisis, and for firms more likely to be financially constrained. We conclude that the usefulness of investment-cash flow sensitivity as a proxy for financial constraints is diminishing over time, even after directly addressing biases from ex-ante subjective sample splitting and various forms of endogeneity.

Originality: We provide new empirical evidence from sharper tests of financial constraints for understudied African firms, and highlight the need to re-look at the usefulness of investment-cash flow sensitivity as a proxy of financial constraints.

Keywords: Financial constraints, Africa, investment-cash flow sensitivity, global financial crisis.

JEL classification: G20, G30, G32

\footnotetext{
*The Faculty of Business and Law, The University of Northampton, Waterside Campus, University Drive, Northampton, NN1 5HP, UK, Email: michael.machokoto@northampton.ac.uk, Tel: +44 160489 3484

†The Faculty of Business and Law, The University of Northampton, Waterside Campus, Northampton, NN1 5PH, UK, Email: Ngozi.Ibeji@northampton.ac.uk, Tel: +44 1604893336

$\neq$ Corresponding author; School of Economic \& Business Sciences, University of the Witwatersrand, 1 Jan Smuts Avenue, Braamfontein, Johannesburg, 2000, South Africa, Email: chimwemwe.chipeta@wits.ac.za, Tel: +27117178145
} 


\section{Introduction}

The effects of financial constraints on real decisions is one of the most contentious issues in corporate finance. To analyse the effects of financial constraints, researchers mostly focus on the relationship between investment and cash flow (investment-cash flow sensitivity). ${ }^{1}$ However, recent evidence on the investment-cash flow nexus is mixed and contradictory, which casts doubt on its usefulness as a proxy of financial constraints. ${ }^{2}$ For example, Brown and Petersen (2009) document a significant decrease in investmentcash flow sensitivity, which they attribute to improvements in access to equity markets and rising R\&D. Chen et al. (2012) find similar decreases for US firms but show that they are pervasive and observable even during the global financing crisis when financial constraints were supposedly more binding. Based on this empirical evidence, they conclude that investment-cash flow sensitivity is not a good proxy of financial constraints. Using a large sample of firms from 41 countries, Moshirian et al. (2017) also document similar patterns in investment-cash flow sensitivity, which they link to the decrease in physical capital intensity and income predictability. Similarly, Rocca et al. (2016) document an overall decrease in investment-cash flow sensitivity for a panel of Italian manufacturing firms over the period 1980-2010. ${ }^{3}$ However, this emerging consensus on the decrease in investment-cash flow sensitivity has been challenged by Lewellen and Lewellen (2016) who find that investment and cash-flow are significantly correlated. They attribute the low or disappearing investment-cash flow sensitivity in recent studies to the noisy measure of cash-flow used (earnings before extraordinary items plus depreciation-to-total assets) and failure to correct for measurement error associated with the firm's future investment opportunities in Tobin's $q$.

\footnotetext{
${ }^{1}$ See, Fazzari et al. (1988), Cleary (1999), Fazzari et al. (2000), Moyen (2004), Pawlina and Renneboog (2005), Guariglia (2008), Brown and Petersen (2009), Mody and Sandri (2012), Lewellen and Lewellen (2016), and Moshirian et al. (2017).

${ }^{2}$ This echoes similar and earlier sentiments by Kaplan and Zingales $(1997,2000)$.

${ }^{3}$ They only find an increase in investment-cash flow during the 2008-09 Global Financial Crisis.
} 
Motivated by the aforementioned mixed results and the dearth of research on Africa, we study the evolution of investment-cash flow sensitivity using a large sample of 5,352 firm-year observations from nine countries around the Global Financial Crisis. ${ }^{4}$ This developing market context is ideal for examining the effects of the Global Financial Crisis on investment-cash flow sensitivity as there is sufficient anecdotal evidence suggesting that African countries were not immune to the adverse effects of the financial crisis even though they have weaker financial linkages with the rest of the world. According to the 2009 African Development Bank (AfDB) Report, African countries, including those that have limited linkages to the global financial economy, were also adversely affected by the Global FinancialCrisis that originated from the US. The2009African Development Bank Report also documents that more open economies such as Nigeria and South Africa experienced massive stock market sell-offs, which resulted in the steepest decline of approximately $67 \%$ and $25.7 \%$ in stock market capitalisation, respectively.

Similarly, Kenya had to contend with a significant drop in portfolio equity flows. According to Allen and Giovannetti (2011), the 2008-09 credit supply shock was mostly transmitted to African economies via the capital account. This is evidenced by the sharp decline in private capital and explains the capital flight reported in Kenya. Against this background, it is not unreasonable to conjecture that investment-cash flow sensitivity should increase as the contractions in credit supply drives a wedge between the cost of internal and external finance. Thus, when faced with an increase in the costs of external finance and contractions in credit supply, firmsturn to internal financing sources such as retained earnings and cash reserves. This increased reliance on internal funds is likely to be more pronounced in bank-based economies, as is the case in most African countries.

\footnotetext{
${ }^{4}$ The extant literature confirms that financial constraints are more severe in developing countries, as is the case with most African countries, due to less developed institutions and capital markets which increase vulnerability to economic shocks and limits the firm's access to external finance (Beck et al., 2009; Gwatidzo and Ojah, 2014; Edjigu and Sim, 2019). However, much of the empirical literature is concentrated to developed countries, mostly the US and UK (see, Fazzari et al., 1988; Cleary, 1999; Guariglia, 2008; Moyen, 2004; Mody and Sandri, 2012).
} 
Therefore, the limited access to external finance, reliance on short-term bank loans and internal funds should strengthen the sensitivity of investment to operating cash flow, especially around the Global Financial Crisis.

Accordingly, we posit that firms operating in Africa have a positive investment-cash flow sensitivity which increases during the Global Financial Crisis, especially for firms more likely to be financially constrained. Consistent with our first prediction, we find a high and significant investment-cash flow sensitivity of 0.148. This significant sensitivity suggests that African firms finance a significant proportion of their investment using operating cash flow as they operate in an environment where access to external finance is much limited. However, our further analyses of the investment-cash flow sensitivity around the Global Financial Crisis show that investment-cash flow sensitivity decreased by $37 \%$ from 0.186 in the pre-crisis period to 0.117 in crisis-period. This decrease, which is robust to using alternative measures of cash flow, sub-sampling and estimation techniques, is inconsistent with our second prediction of a marked increase in investment-cash flow sensitivity due to the increase in financial constraints around the Global Financial Crisis. Our findings differ from Moshirian et al. (2017) who find that investment-cash flow sensitivity is diminishing only in developed economies but remains relatively stable in developing economies. Instead, this affirms the findings of Chen and Chen (2012) in the USand emphasise theneed to develop alternative measures of financial constraints as economies are increasingly shifting from physical and tangible investments towards R\&D and intangibles.

Our further analyses using panel threshold models that are immune to ex-ante sample splitting biases of firms into constrained and unconstrained regimes reveal similar decreases in investment-cash flow sensitivity. Specifically, we find that constrained firms have significantly higher investment-cash flow sensitivity relative to unconstrained firms. This significant difference is contrary to Rocca et al. (2016) who find marginal or in- 
significant differences in investment-cash flow sensitivity between constrained and unconstrained Italian manufacturing firms. Our findings are also inconsistent with Arslan et al. (2006) who document higher investment-cash flow sensitivity for constrained firms around the 2001-2002 Turkish financial crisis, and Rocca et al. (2016) who report an increase in investment-cash flow sensitivity around the Global Financial Crisis of 200809. Instead, our results show that both constrained and unconstrained firms experience similar decreases in investment-cash flow sensitivity during the 2008-09 Global Financial Crisis. This finding is contrary to expectations that the 2008-09 credit supply shock resulted in severe financial constraints, more so, in developing countries where access to finance is limited. Based on our results, which are robust to using alternative proxies of financial constraint proxies, we conclude that the usefulness of investment-cash flow sensitivity as a proxy of financial constraints has diminished.

Next, we explore whether some of the reasons advanced in the literature explain this decrease in investment-cash flow sensitivity (see, Pawlina and Renneboog, 2005; Brown and Petersen, 2009; Moshirian et al., 2017). Contrary to the literature, we find that factors - such as agency costs (Pawlina and Renneboog, 2005; Andrn and Jankensgrd, 2015), the rise in R\&D (Brown and Petersen, 2009), the decrease in physical investment (Moshirian et al., 2017) and capital market developments (Brown and Petersen, 2009) - do not explain the decrease in investment-cash flow sensitivity that we document within the African context. Thus, by using panel thresholds models with unknown sample separation and focusing on the effects of a rare exogenous credit supply shock in a unique setting (African context), we provide new empirical evidence from sharper tests of financial constraints and highlight the need to re-look at the usefulness of investment-cash flow sensitivity as a proxy of financial constraints.

The rest of this paper is organised as follows. Section 2 discusses hypotheses. Section 3 lays out our empirical framework. Section 4 provides information about the data used. 
Section 5 discusses our findings. Section 6 presents the robustness tests, while Section 7 concludes the study and provides recommendations for future research.

\section{Literature and hypotheses}

Several studies have documented an increase in financial constraints during financial crises. For example, a survey by Campello et al. (2010) shows that firms cut back on $\mathrm{R} \& \mathrm{D}$, employment and investment, and sold off assets to wither-off the adverse effects of the Global Financial Crisis. Similar adverse effects of the Global Financial Crisis were documented by Duchin et al. (2010), Akbar et al. (2013) and Almeida et al. (2014). In a related study, Arslan et al. (2006) find that financially constrained firms exhibit higher investment-cash flow sensitivity relative to their unconstrained counterparts and that the differences are more pronounced during the 2001-2002 Turkish financial crisis. In the context of a developing market where access to external finance is restricted, a credit supply shock such as the 2008-09 Global Financial Crisis should result in increased reliance on internal financing sources. As a consequence, we expect to observe an increase in the sensitivity of investment to internal cash flows, especially for our sample of firms in developing economies where access to external finance is limited. Accordingly, we formulate and test the following hypothesis:

Hypothesis 1 (H1): Investment-cash flow sensitivity increases during the Global Financial Crisis.

A considerable number of studies link investment-cash flow sensitivity to financial constraints (see, Fazzari et al., 1988; Alti, 2003; Moyen, 2004; Pawlina and Renneboog, 2005; Khurana et al., 2006; Hovakimian, 2009; Brown and Petersen, 2009; Chang et al., 2014; Lewellen and Lewellen, 2016; Drobetz et al., 2016; Agca and Mozumdar, 2017; Drobetz et al., 2017; Moshirian et al., 2017). This arises due to the high wedge between the costs 
of internal and external funds, and the limited access to external capital sources. As a consequence, financially constrained firms are more dependent on internally generated funds to finance their investments. According to Kaplan and Zingales (1997) and Lyandres (2007), the wedge between internal and external financing sources is relatively higher for financially constrained firms, which makes external financing costly, more so, during periods of heightened uncertainty such as the Global Financial Crisis. However, Kahle and Stulz (2013) find that the effects of the Global Financial Crisis were not different between supposedly constrained and unconstrained firms. Specifically, they find that the increase in uncertainty with the onset of the financial crisis resulted in similar decreases in capital expenditures irrespective of the financial characteristics of the firms. This makes it a prioriunclear how the financial crisis affected firms in the US, and more so, in other countries with different institutional frameworks. For our special case of developing markets with institutional voids, we expect investment-cash flow sensitivity to increase, with this increase being more pronounced for financially constrained firms relative to their unconstrained counterparts. This drives a wedge between internal and external finance, especially during contractions in credit supply (see Campello and Giambona, 2013), which increases reliance on internally generated cash flows. Taken together, the evidence discussed leads us to formulate and test the following hypothesis:

Hypothesis 2 (H2): Financially constrained firms exhibit higher investment-cash flow sensitivity relative to unconstrained firms, with this difference being more pronounced during the Global Financial Crisis. 


\section{Methodology}

To examine the effects of the Global Financial Crisis (GFC) on investment-cash flow sensitivity, we estimate the following augmented investment model:

$$
\begin{gathered}
I_{i j k t=a_{1}} q_{i j k t-1}+a_{2} C F_{i j k t}+a_{3} \text { Crisist }+a_{4} C F_{i j k t} \times \text { Crisist } \\
+\boldsymbol{\beta} \boldsymbol{X}_{i j k t-1}+\mu_{i}+\eta_{k t}+E_{i j k t}
\end{gathered}
$$

where $I_{i j k t}$ is the ratio of physical capital investment-to-total assets for firm $i$ in industry $j$ and country $k$ at time $t, a_{1}-a_{4}$ and $\boldsymbol{\beta}$ are parameters to be estimated, $C F_{i j k t}$ is the firm'soperating cash-flow-to-total assets, Crisist is a dummyvariablethat takes thevalue of one for the period 2008-2012 and otherwise, zero ${ }^{5}, \boldsymbol{X}_{i j k t-1}$ is vectors of firm-specific characteristics explained below, $\mu_{i}$ and $\eta_{j k t}$ are the firm-fixed effects and country-year fixed effects, respectively, and $E_{i j k t}$ is the error term. ${ }^{6}$ The vector, $\boldsymbol{X}_{i j k t-1}$, consists of $q$ - market of equity plus total debt-to-total assets, Cash - cash and cash equivalentto-total assets, Leverage - total debt-to-total assets and Size - the logarithm of total assets.

Following Hansen (1999, 2000), we next estimate the following panel threshold model to examine the effects of financial constraints on investment-cash flow sensitivity:-

$$
I_{i j k t}=\boldsymbol{\lambda}\left(C F_{i j k t}+C F_{i j k t} \times C r i s i s t\right)\left(c_{i j k t, \gamma}\right)+\boldsymbol{\beta} \boldsymbol{X}_{i j k t-1}+\xi_{i j k t}
$$

where $c_{i j k t}$ is the threshold variable, $\gamma$ is the threshold parameter that partitions the equation into regimes, and $\xi_{i j k t}$ is the error term. For the threshold variables, we use six

\footnotetext{
${ }^{5}$ In this study, we define the crisis using a longer period as this enables us to capture the long-term effects of the GFC on corporate decisions. In addition, other studies such as Dang et al. (2014) and Machokoto (2020) use a similar period to investigate the effect of the GFC on corporate decisions.

${ }^{6}$ As the industry is time-invariant within firms, the firm fixed effects subsume the industry fixed effects.
} 
proxies of financing constraints - size (the logarithm of total assets), WW Index (Whited and Wu, 2006), KZ Index (Kaplan and Zingales, 1997), HP Index (Hadlock and Pierce, 2010), dividends (dividend-to-total assets), tangibility (property, plant and equipmentto-total assets), leverage (total debt-to-total assets), and Z-Score (Altman, 1968). The literature informs our choice of threshold variables (financial constraint proxies) (Almeida and Campello, 2007; Almeida et al., 2010; Chen and Chen, 2012; Moshirian et al., 2017). We use the panel threshold model as the conventional linear model becomes misspecified in the presence of heterogeneity or structural breaks (Hansen, 2000; Wang, 2015). The extant literature uses an ex-ante sample-splitting or dummy variable approach (a cutoff or breakpoint such as (upper) lower terciles or median (mean) of a variable of interest) to investigate asymmetries or heterogeneity in corporate decisions (Chen and Chen, 2012; Chang et al., 2014; Lewellen and Lewellen, 2016). However, this approach is often arbitrary (judgemental). It could introduce sample selection bias (Hansen, 2000) as the extent to which a particular firm is likely to be constrained or unconstrained is not directly observable (Hovakimian and Titman, 2006). A panel threshold model, therefore, provides sharpertests of financial constraints as thethreshold is unknown and endogenously determined. This approach is in contrasts to the ex-ante sample splitting approach that could inadvertently bias the inferences on the extent to which financial constraints affect corporate decisions.

For robustness, we also use the ex-ante sample splitting approach and categorise a firm in each year as constrained (unconstrained) if it is below (above) the median distribution of the logarithm of market capitalisation (MktCap), firm-age and tangibility. For the exante categorisations based on the WW Index (Whited and Wu, 2006), we consider a firm to be constrained (unconstrained) if it is above (below) the median distribution of the WW Index in each year. The median is used to categorise firms into regimes rather than the upper (lower) quartiles or deciles as this reduces the likelihood of finding significant 
cross-sectional differences between the constrained and unconstrained sub-samples. ${ }^{7}$ To ensure the robustness of our results and facilitate comparisons with prior studies, we estimate our models using three commonly used estimators; the pooled ordinary least squares(OLS), fixed effects(FE) and instrumentalvariables(IV). Forthe2SLSestimator, we use the second lag of Tobin's $q$ as an instrument to address potential endogeneity and mismeasurement errors associated with future growth opportunities in Tobin's $q$. We also use the GMM estimator of Erickson and Whited (2000, 2002) (GMM5), instrumental variables GMM (IV-GMM) (Baum et al., 2003), dynamic fractional dependent variables (DPF) (Elsas et al., 2013; Elsas and Florysiak, 2015), difference GMM (DIF-GMM) (Arellano and Bond, 1991) and system GMM (SYS-GMM) (Blundell and Bond, 1998) in our further robustness tests. ${ }^{8}$

\section{Data}

Our sample consists of annual data of publicly listed firms from nine African countries over the period 2003-2012. We exclude utility and financial firms, and those with negative equity and missing key observations. We winsorise all variables used at the lower and upper one percentile to reduce the effect of possibly spurious outliers. Our final sample is an unbalanced panel consisting of 5,352 firm-year observations (873 firms) from Egypt, Ivory Coast, Kenya, Ghana, Morocco, Nigeria, South Africa, Tunisia and Zambia. All variables used are ratios except for size and the dummy variables and are defined in Table 1.

\section{PLEASE INSERT TABLE 1 HERE}

Table 1 presents the summary statistics for all variables. Panel A shows that the mean

\footnotetext{
${ }^{7}$ Appendix A presents qualitatively similar results for estimations based on the ex-ante categorisation of firms into constrained and unconstrained regimes.

${ }^{8}$ The general method of moments (GMM5) estimator of Erickson and Whited $(2000,2002)$ uses higher-order moments to address potential mismeasurement errors associated with Tobin's $q$.
} 
(median) investment (I), Tobin's $q(q)$, cash flow (CF), cash, leverage and size are 0.081 (o.061), 0.218 (0.203), 0.137 (0.102), 0.159 (0.133), 1.650 (1.412), and 14.787 (14.966), respectively. These summary statistics are as expected and in line with prior studies. More importantly, comparisons of the pre-crisis and crisis periods show that significant decreases in investment, Tobin's $q$ and cash flow, and increases in cash, debt and size. For the changes in measures of financial constraints around the financial crisis, we find that debt, size, the HP Index, dividends and LogPPE have increased, while the WW Index, KZ Index and Z-Score have decreased. ${ }^{9}$ This makes it a priori unclear whether firms faced more (or less) constraints around the financial crisis, which motivates us to explore this issue further.

\section{PLEASE INSERT TABLE 2 HERE}

Table 2 presents pairwise correlations. The correlations show that investment is positively correlated with Tobin's $q$, cash flow, debt and size, while it is negatively correlated with cash. This shows that cash flow significantly influences investment as is consistent with our hypothesis. The other correlations are of the expected sign.

\section{Empirical Findings}

Table 3 summarises the estimation results of Equation (1), which relates investment to Tobin's q, cash flow, crisis dummy, the interaction of the crisis dummy and cash flow, and control variables.

\section{PLEASE INSERT TABLE 3 HERE}

\footnotetext{
${ }^{9}$ These do not provide a firms absolute measure of financial constraint but rather its position relative its counterparts (categorisation). Hence, our focus on the changes in investment and its sensitivity to internal funds (ICFS) around the financial crisis rather than changes in proxies of financial constraints per se, which are less informative and do not have a direct interpretation, except for drawing comparisons across firms.
} 
Column (1) shows a significant investment-cash flow sensitivity of 0.148 , which is much higher than estimates of $0.001-0.05$ reported in the literature for advanced economies (see, Brown and Petersen, 2009; Chen and Chen, 2012; Moshirian et al., 2017). This high investment-cash flow sensitivity is consistent with the notion that firms in developing economies are more reliant on internal operating cash flows to finance their investments due to limited access to external finance. We find similar estimates of investment-cash flow sensitivity in Columns (4) and (7) when we use fixed effects (FE) and instrumental variables (IV) estimation techniques, respectively. This suggests that our estimates of investment-cash flow sensitivity are robust to the choice of estimation technique. The results of control variables are as expected and in line with prior studies (see, Guariglia and Yang, 2016; Moshirian et al., 2017), except for cash which appears to suggest that firms in developing markets tend to increase savings by reducing or postponing investments. For brevity, we only further discuss the variables of interest.

Next, we examine the effects of the Global Financial Crisis on investment-cash flow sensitivity in Columns (2), (5) and (8). Our results show a significant decrease in investment-cash flow sensitivity during the crisis period. Specifically, the OLS estimates of investment-cash flow sensitivity show a decrease of $37 \%$, while those for fixed effects and instrumental variables suggest a decrease of $39 \%$ and $67 \%$, respectively. These decreases arenotinline with Hypothesis (1), which predicts an increase in theinvestment-cash flow sensitivity around the Global Financial Crisis. Instead, the significant decrease appears to suggest the opposite and is contrary to US studies that report a significant increase in financial constraints around the Global Financial Crisis (see, Campello et al., 2010; Duchin et al., 2010; Almeida et al., 2012).

So far, we have only controlled for Tobin's $q$ in our regressions. Thus our estimates of investment-cash flow sensitivity might suffer from omitted variable bias. We address this concern by controlling for cash, debt and size, which are the other main determinants 
of investment from the literature (see, Moyen, 2004; Chen and Chen, 2012; Moshirian et al., 2017). As the results in Columns (3), (6) and (9) show, the inclusion of these additional determinants does not change our main findings. The $\mathrm{CF} \times$ Crisis remains negative and significant, as shown in Columns (2), (5) and (8). This shows that the decrease in investment-cash flow sensitivity is robust to controlling for other determinants of investment and using different estimation techniques. We conclude that our data do not support Hypothesis (1). However, at this stage of our analysis, we cannot rule out the possibility that changes in investment-cash flow sensitivity around the Global Financial Crisis might vary across firms in a way that supports Hypothesis (2).

We next extend our analysis by presenting the results estimating Equation (2) that captures the threshold effects of financial constraints on investment-cash flow sensitivity around the Global Financial Crisis. Table 4 summarises the results for the threshold based on each of the eight proxies of financial constraints: size, WW Index (Whited and Wu, 2006), KZIndex (Kaplan andZingales, 1997), HP Index (Hadlock and Pierce, 2010), dividends, tangibility, leverage and Z-Score (Altman, 1968).

\section{PLEASE INSERT TABLE 4 HERE}

Panel A of Table 4, which excludes the crisis dummy and its interaction with cash flow, show significant threshold effects of financial constraints on investment-cash flow sensitivity. The results show significant threshold effects of financial constraints on investmentcash flow sensitivity. Specifically, we find that the coefficient of $\mathrm{CF}^{\mathrm{C}}$, for constrained firms, is significantly higher than $\mathrm{CF}^{\mathrm{U}}$ (for unconstrained firms), except for thresholds based on tangibility (Column (6)) and Z-Score (Column (8)). For the most part, the evidence on threshold effects is supportive of Hypothesis (2)and consistent with the findings of Lewellen and Lewellen (2016). This suggests that constrained firms rely mostly on internal sources of financing relative to unconstrained firms with better access to external finance. The high investment-cash flow sensitivity for firms with high tangibility is not 
surprising as these firms are heavily invested in physical capital, which should naturally lead to high sensitivity to cash flow. The inconsistent result for the threshold based on the Z-Scorehighlights the controversy surrounding this measure as a proxy for financial constraints.

Next, Panel B shows the effects of the Global Financial Crisis on investment-cash flow sensitivity. Again as in Panel A, we find significant and consistent threshold effects of financial constraints on the sensitivity of investment to cash flow (investment-cash flow sensitivity). This highlights significant cross-sectional heterogeneity in investment-cash flow sensitivity based on our eight proxies of financial constraints. The coefficient of CF for both constrained and unconstrained firms $\left(\mathrm{CF}^{\mathrm{C}}\right.$ and $\left.\mathrm{CF}^{\mathrm{U}}\right)$ in the pre-crisis period is similarly positive and significant as in Panel A. However, we find that the coefficients of the interactive term of cash flow and the crisis dummy, $\mathrm{CF}^{\mathrm{C}} \times$ Crisis and $\mathrm{CF}^{\mathrm{U}} \times$ Crisis, are consistently negative and significant. ${ }^{10}$ This finding is contrary to Hypothesis (2), which suggests that the decrease in investment-cash flow sensitivity around the crisis is robust to how financial constraints are measured. This casts doubt on the usefulness of investment-cash flow sensitivity as a proxy of financial constraints. ${ }^{11}$ To the extent that there was a credit supply shock over the period 2008-09, investment-cash flow sensitivity should have increased significantly if its truly a proxy of financial constraints, especially, for firms more likely to be constrained in Africa where access to finance is limited.

In the remaining parts of this study, we examine whether factors identified in the literature explain the decrease in investment-cash flow sensitivity around the Global Financial Crisis. To accomplish this objective, we test whether factors such as agency costs (Pawlina and Renneboog, 2005; Andrn and Jankensgrd, 2015; Guariglia and Yang,

\footnotetext{
${ }^{10}$ This result is not in line with Moshirian et al. (2017) who attribute the decrease in investment-cash flow sensitivity to the decrease in the share of tangible capital on corporate balance sheets. Instead, our result suggests that the decrease in investment-cash flow sensitivity is robust as it is significant for both firms with low and high physical capital intensity.

${ }^{11}$ Appendix B presents qualitatively similar results for the sub-periods.
} 
2016), the rise in $R \& D$ (Brown and Petersen, 2009), the decrease in physical investment (Moshirian et al., 2017), stock market developments (Brown and Petersen, 2009) and the noise in the cash flow variable (Lewellen and Lewellen, 2016) explain the decrease in investment-cash flow within the African context. The results of the factors explaining investment-cash flow sensitivities are presented in Table 5 .

\section{PLEASE INSERT TABLE 5 HERE}

To test the effects of agency costs on investment-cash flow sensitivity, in Table 5, we partition the sample into four sub-groups based on whether the firm is above or below the median of lagged investment and cash flow. Guariglia and Yang (2016) use a similar approach where they classify firms with high-cash flow and low-investment as being more subject to agency costs relating to under-investment and diversions of free cash flows, while those with high cash flow and high-investment are likely to over-invest. Following on Hypothesis 1, the credit supply shock emanating from the financial crisis should increase investment-cash flow sensitivity, especially for firms facing higher agency costs.

However, we find no supporting evidence for this prediction across the four subgroups of firms. Specifically, the coefficient on $\mathrm{CF} \times$ Crisis for the firms that are less likely subject to agency costs, low-CF and low-investment in Column (1), is positive but not significant, which shows that firms less prone to agency costs record an insignificant increase in investment-cash flow sensitivity around the financial crisis. At the same time, the coefficient on $\mathrm{CF} \times$ Crisis in Column (2), for low-CF and high-investment, is negative and significant, which is also inconsistent with our prediction that such firms should experience an increase in investment-cash flow sensitivity during the crisis. This finding is puzzling, especially in the context of developing markets where access to external capital is limited. In such a case, one would expect supposedly constrained firms with high investments to have a high investment-cash flow sensitivity, especially during the 
2008-09 contractions in credit supply. Similarly, in Columns (3) and (4), for firms supposedly subject to high agency costs (high-CF \& low-I - firms that have high cash flow but low investment, and high-CF \& high-I - firms that have high cash flow and high investment), we find that the coefficients on $\mathrm{CF} \times$ Crisis are negative but not significant. ${ }^{12}$ Taken together, our results suggest that agency costs as put forward by Pawlina and Renneboog (2005), Andrn and Jankensgrd (2015) and Guariglia and Yang (2016) do not explain the decrease in investment-cash flow sensitivity with the African context.

In Column (5) of Table 5, we include R\&D in the regression model as Brown and Petersen (2009) shows that the decrease in investment-cash flow sensitivity in the US correlates with the marked increase in $\mathrm{R} \& \mathrm{D}$. Wefind that the coefficient of $\mathrm{CF} \times \mathrm{Crisis}$ remains negative even after incorporating R\&D, as shown in Column (5). Next, in Column (6), we examine the changes in investment-cash flow sensitivity based on total investments (physical capital investment plus R\&D) rather than physical capital investments. Again, we find a significant negative coefficient on $\mathrm{CF} \times \mathrm{Crisis}$, which suggests that changes in R\&D do not similarly explain the decrease in investment-cash flow sensitivity within the African context.

We further include tangibility (PPE), the trend variable and the lagged median investment (Med-I) in Columns (7), (8) and (9), respectively, as additional determinants of investment. We include the lagged median investment (Med-I) as an additional control variable in order to purge common industrial changes in investment. Columns (7)-(9) show that the decrease in physical capital investment and intensity as put forward by Moshirian et al. (2017) does not explain the decrease in investment-cash flow sensitivity in our case as the coefficient of $\mathrm{CF} \times$ Crisis is negative. Our untabulated results further show that both physical capital investment and intensity do not change significantly and in a

\footnotetext{
${ }^{12}$ Managers of firms with high cash flows and low investment opportunities are more likely to consume private benefits from the idle cash balances. In contrast, firms that have high cash flows and high investments are more likely to over-invest. We, therefore, expect higher investment-cash flow sensitivities for firms in the latter group.
} 
way that can explain the reduction in investment-cash flow sensitivity over the sample period as African firms are still heavily invested in physical capital (tangible investments or assets).

Finally, in Columns (10)-(11) and (12)-(13) we control for changes in capital markets and noise in cash flow, respectively. In Columns (10) and (11) of Table 5, we find that our results remain qualitatively similar if we control for changes in capital markets by including stock market capitalisation-to-GDP (SMGDP) and domestic credit-to-GDP (PDCGDP) as additional control variables. ${ }^{13}$ To ensure that our results are robust to noise in the measure of the cash flow variable, in Columns (12) and (13), we use an augmented definition of cash flow, earnings before interest, taxes, depreciation, and amortisation (EBITDA) plus $\Delta \mathrm{WC}$ (WC - change in working capital) -to-total assets. These additional analyses are motivated by Lewellen and Lewellen (2016) who shows that the low investment-cash flow sensitivity reported in the literature could be driven by the use of noisy measures or proxies of cash flow. Using the augmented measure of cash flow as proposed by Lewellen and Lewellen (2016), we find, in Columns (12) and (13) of Table 5, no supporting evidence of an increase in investment-cash flow sensitivity during the financial crisis. These findings suggest that the evolution of investment-cash flow sensitivity that we document is unlikely to be driven by the noise in the cash flow variable.

Overall, our results are inconsistent with Hypothesis (2) and at the same time show that none of the factors advanced in the literature explains the decrease in investmentcash flow sensitivity that we document around the Global Financial Crisis in Africa. This new empirical evidencesuggests that investment-cash flowsensitivity is not agood proxy for financial constraints, which highlights the need to re-look new proxies for financial constraints.

\footnotetext{
${ }^{13}$ The stock market capitalisation-to-GDP (SMGDP) and domestic credit-to-GDP (PDCGDP) are from the World Bank Database.
} 


\section{Robustness}

To test the robustness of our results, we re-estimate Equation (1) for each country and using 5-year rolling regressions for the unbalanced and balanced samples. ${ }^{14}$ Table 6 summarises thetime-series and cross-country estimates of investment-cash flow sensitivity.

\section{PLEASE INSERT TABLE 6 HERE}

Panel A of Table 6 presents the results of the rolling regression for the six rolling subperiods. For the unbalanced sample, investment-cash flow sensitivity rises initially from 0.204 overthe period 2003-2007 to a peak of 0.236 over the period 2004-2008. It then declines over the following three consecutive rolling sub-periods to close at 0.078 for the period 2006-2010. Although there is a slight increase over the period 2007-2011, the coefficient declines again to o.080 during the Global Financial Crisis. Additionally, the estimates of investment-cash flow sensitivity for the balanced sample consistently decline from a peak of 0.175 over the period 2003-2007 to 0.019 for the period 2007-2011, and then rises marginally to 0.032 over the period 2008-2012. However, investment-cash flow sensitivity is insignificant for rolling sub-samples after the period 2006-2010. ${ }^{15}$ These results are consistent with our main findings and show that the decrease in investmentcash flow sensitivity cannot be attributed to the changing composition of firms as put forward by Moshirian et al. (2017). In Africa, the composition of firms is relatively stable as there are few entry and exits over the sample period. Hence, our results are unlikely to be driven by the influx of small and young firms as observed in the USA by Fama and French (2001, 2004). ${ }^{16}$

\footnotetext{
${ }^{14} \mathrm{We}$ use rolling regressions as the observations in developing markets are limited to allow for meaningful sub-period analyses. Further, using rolling regressions is advantageous as it allows for fixed effects to vary across sub-samples (Chen and Chen, 2012).

${ }^{15}$ Appendix $\mathrm{C}$ shows that our results are robust to changing the way we define or identify the crisis period and including dividends in our model to account for the simultaneity of corporate decisions (see Gatchev et al., 2010; Hoang and Hoxha, 2019).

${ }^{16}$ In Columns (6) and (7) of Appendix C, we find that firms in both the Sub-Saharan African (SSA)
} 
We next re-estimate Equation (1) using the GMM estimator of Erickson and Whited (2000, 2002) (GMM5), instrumental variables GMM (IV-GMM) (Baum et al., 2003), dynamic fractional dependent variables (DPF) (Elsas et al., 2013; Elsas and Florysiak, 2015), difference GMM (DIF-GMM) (Arellano and Bond, 1991) and system GMM (SYSGMM) (Blundell and Bond, 1998). Using the other estimation techniques as highlighted earlier in Section 3 ensures comparability with prior studies, and at the same time, provides a way of checking the robustness of our results. Table 7 summarises the results.

\section{PLEASE INSERT TABLE 7 HERE}

Columns (1)-(5) of Table 7, which present results for regressions excluding control variables, show that the financial crisis had a significant and consistent negative effect on both investment and investment-cash flow sensitivity. Across Columns (1)-(5), investment-cash flow sensitivity decreases by $26 \%-64 \%$, which is in line with our main results. These results do not change when we include other control variables in Columns (6) -(10). The investment-cash flow sensitivity estimates based on the GMM5 of Erickson and Whited (2000,2002) are much higher relativetothose based on other estimation techniques. At the same time, they show a marginally significant or insignificant decrease in the investment-cash flow sensitivity during the financial crisis, which is at odds with our main results. These results are not surprising given that several studies highlight that estimates of investment-cash flow sensitivity based on the higher-order moments estimator of Erickson and Whited (2000, 2002) (GMM5 in our case) appear to be economically implausible at times (Almeida et al., 2010; Chang et al., 2014; Lewellen and Lewellen, 2016). This appears to be the case in Columns (1) and (6) of Table 7. Therefore, we conclude that the decrease in investment-cash flow sensitivity that we document is robust to potential mismeasurement errors associated with Tobin's q, controlling for other and North African (NA) regions experience a significant decrease in ICFS. This finding suggests that the decrease in ICFS around the financial crisis is not localised to a particular region. 
determinants of investment, the choice of the estimation technique and accounting for the dynamic nature of the corporate decisions.

\section{Conclusion}

This study is motivated by the recent empirical findings that the relationship between investment and cash flow is remarkably disappearing over time. These findings are in stark contrast to the vast literature documenting a strong investment-cash flow relationship, which is interpreted as a proxy for financial constraints. We extend this line of inquiry to understudied African firms and use the 2008-09 credit supply shock as a quasinatural experiment. We use panel thresholds models with unknown sample separation to affirm the decrease in investment-cash flow sensitivity when its most expected to increase, especially, in a developing market context whereaccess to external financeislimited. This new and direct evidence from developing countries highlights the need for further research in this area as the usefulness of investment-cash flow sensitivity, the commonly used proxy for financial constraints, is diminishing over time. One possible avenue in resolving this issue is to examine the information content of cash flow regarding future investments, especially during crises or around major economic events. Additionally, future studies could consider whether improvements in corporate governance (e.g. the implementation of the King's Report on Corporate Governance for the case of South Africa) and the rising corporate debt in developing markets (which is an alternative source of financing for investments) are factors driving the decrease in investment-cash flow sensitivity.

\section{Data Availability}

The data that support the findings of this study is available from Thomson Reuters Datastream. Restrictions may apply to the availability of this data, which was used 
under license.

\section{Acknowledgement}

We wish to acknowledge the helpful input of Daniel Gyimah, Nadeem Aftab, Thaana Ghalia, Ali Shakil Khan, Ahmad Haboub and seminar participants at the University of Northampton and University of the Witwatersrand. Chimwemwe Chipeta wishes to acknowledge funding received from Oppenheimer Memorial Trust. The usual disclaimer applies. 


\section{References}

Agca, S. and Mozumdar, A. (2017). InvestmentCash Flow Sensitivity: Fact or Fiction? Journal of Financial and Quantitative Analysis, 52(3):1111-1141.

Akbar, S., Rehman, S., and Ormrod, P. (2013). The Impact of Recent Financial Shocks on the Financing and Investment Policies of UK Private Firms. International Review of Financial Analysis, 26:59-70.

Allen, F. and Giovannetti, G. (2011). The effects of the financial crisis on Sub-Saharan Africa. Review of Development Finance, 1(1):1-27.

Almeida, H. and Campello, M. (2007). Financial Constraints, Asset Tangibility, and Corporate Investment. Review of Financial Studies, 20(5):1429-1460.

Almeida, H., Campello, M., Cunha, I., and Weisbach, M. S. (2014). Corporate Liquidity Management: A Conceptual Framework and Survey. Annual Review of Financial Economics, 6(1):135-162.

Almeida, H., Campello, M., and Galvao, A. F. (2010). Measurement Errors in Investment Equations. The Review of Financial Studies, 23(9):3279-3328.

Almeida, H., Murillo, C., Bruno, L., and Scott, W. (2012). Corporate Debt Maturity and the Real Effects of the 2007 Credit Crisis. Critical Finance Review, 1(1):3-58.

Alti, A. (2003). How Sensitive Is Investment to Cash Flow When Financing Is Frictionless? The Journal of Finance, 58(2):707-722.

Altman, E. I. (1968). Financial Ratios, Discriminant Analysis and the Prediction of Corporate Bankruptcy. The Journal of Finance, 23(4):589-609.

Andrn, N. and Jankensgrd, H. (2015). Wall of cash: The investment-cash flow sensitivity when capital becomes abundant. Journal of Banking \& Finance, 50:204-213. 
Arellano, M. and Bond, S. (1991). Some Tests of Specification for Panel Data: Monte Carlo Evidence and an Application to Employment Equations. The Review of Economic Studies, 58(2):277-297.

Arslan, O., Florackis, C., and Ozkan, A. (2006). The role of cash holdings in reducing investmentcash flow sensitivity: Evidence from a financial crisis period in an emerging market. Emerging Markets Review, 7(4):320-338.

Baum, C. F., Schaffer, M. E., and Stillman, S. (2003). Instrumental Variables and GMM: Estimation and Testing. The Stata Journal, 3(1):1-31.

Beck, T., Fuchs, M., and Uy, M. (2009). Finance in Africa - Achievements and Challenges. Technical Report WPS5020, The World Bank, Washington, D.C., USA.

Blundell, R. and Bond, S. (1998). Initial Conditions and Moment Restrictions in Dynamic Panel Data Models. Journal of Econometrics, 87(1):115-143.

Brown, J. R. and Petersen, B. C. (2009). Why has the Investment-Cash Flow Sensitivity Declined so Sharply? Rising R\&D and Equity Market Developments. Journal of Banking \& Finance, 33(5):971-984.

Campello, M. and Giambona, E. (2013). Real Assets and Capital Structure. The Journal of Financial and Quantitative Analysis, 48(5):1333-1370.

Campello, M., Graham, J. R., and Harvey, C. R. (2010). The real effects of financial constraints: Evidence from a financial crisis. Journal of Financial Economics, 97(3):470-487.

Chang, X., Dasgupta, S., Wong, G., and Yao, J. (2014). Cash-Flow Sensitivities and the Allocation of Internal Cash Flow. The Review of Financial Studies, 27(12):3628-3657. 
Chen, H. J. and Chen, S. J. (2012). Investment-Cash Flow Sensitivity Cannot be a Good Measure of Financial Constraints: Evidence from the Time Series. Journal of Financial Economics, 103(2):393-410.

Chen, Q., Chen, X., Schipper, K., Xu, Y., and Xue, J. (2012). The Sensitivity of Corporate Cash Holdings to Corporate Governance. Review of Financial Studies, 25(12):3610-3644.

Cleary, S. (1999). The Relationship between Firm Investment and Financial Status. The Journal of Finance, 54(2):673-692.

Dang, V. A., Kim, M., and Shin, Y. (2014). Asymmetric Adjustment Toward Optimal Capital Structure: Evidence from a Crisis. International Review of Financial Analysis, $33: 226-242$.

Drobetz, W., Haller, R., and Meier, I. (2016). Cash flow sensitivities during normal and crisis times: Evidence from shipping. Transportation Research Part A: Policy and Practice, 90:26-49.

Drobetz, W., Haller, R., Meier, I., and Tarhan, V. (2017). The impact of liquidity crises on cash flow sensitivities. The Quarterly Review of Economics and Finance, 66:225239.

Duchin, R., Ozbas, O., and Sensoy, B. A. (2010). Costly External Finance, Corporate Investment, and the Subprime Mortgage Credit Crisis. Journal of Financial Economics, $97(3): 418-435$.

Edjigu, H. T. and Sim, N. (2019). Does the Presence of Foreign Firms Reduce Domestic Firms Financial Constraints in Sub-Saharan Africa? Journal of African Economies, 28(4):1-28. 
Elsas, R., Flannery, M. J., and Garfinkel, J. A. (2013). Financing Major Investments: Information about Capital Structure Decisions. Review of Finance, 18(4):1341-1386.

Elsas, R. and Florysiak, D. (2015). Dynamic Capital Structure Adjustment and the Impact of Fractional Dependent Variables. Journal of Financial and Quantitative Analysis, 50(5):1105-1133.

Erickson, T. and Whited, T. M. (2000). Measurement Error and the Relationship between Investment and q. Journal of Political Economy, 108(5):1027-1057.

Erickson, T. and Whited, T. M. (2002). Two-Step GMM Estimation of the Errors-inVariables Model Using High-Order Moments. Econometric Theory, 18(3):776-799.

Fama, E. F. and French, K. R. (2001). Disappearing Dividends: Changing Firm Characteristics or Lower Propensity to Pay? Journal of Financial Economics, 6o(1):3-43.

Fama, E. F. and French, K. R. (2004). New Lists: Fundamentals and Survival Rates. Journal of Financial Economics, 73(2):229-269.

Fazzari, S. M., Hubbard, R. G., and Petersen, B. C. (1988). Financing Constraints and Corporate Investment. Brookings Papers on Economic Activity, 1(1):141-195.

Fazzari, S. M., Hubbard, R. G., and Petersen, B. C. (2000). Investment-Cash Flow Sensitivities are Useful: A Comment on Kaplan and Zingales. The Quarterly Journal of Economics, 115(2):695-705.

Gatchev, V. A., Pulvino, T., and Tarhan, V. (2010). The Interdependent and Intertemporal Nature of Financial Decisions: An Application to Cash Flow Sensitivities. The Journal of Finance, 65(2):725-763.

Guariglia, A. (2008). Internal Financial Constraints, External Financial Constraints, 
and Investment Choice: Evidence from a Panel of UK Firms. Journal of Banking \& Finance, 32(9):1795-1809.

Guariglia, A. and Yang, J. (2016). A balancing act: Managing financial constraints and agency costs to minimize investment inefficiency in the Chinese market. Journal of Corporate Finance, 36(1):111-130.

Gwatidzo, T. and Ojah, K. (2014). Firms Debt Choice in Africa: Are Institutional Infrastructure and Non-Traditional Determinants Important? International Review of Financial Analysis, 31:152-166.

Hadlock, C. J. and Pierce, J. R. (2010). New Evidence on Measuring Financial Constraints: Moving Beyond the KZ Index. The Review of Financial Studies, 23(5):19091940.

Hansen, B. E. (1999). Threshold Effects in Non-Dynamic Panels: Estimation, Testing, and Inference. Journal of Econometrics, 93(2):345-368.

Hansen, B. E. (2000). Sample Splitting and Threshold Estimation. Econometrica, 68(3):575-603.

Hoang, E. and Hoxha, I. (2019). An international study of the response of corporate payout policy. International Journal of Managerial Finance, 15(3):335-349.

Hovakimian, G. (2009). Determinants of Investment Cash Flow Sensitivity. Financial Management, 38(1):161-183.

Hovakimian, G. and Titman, S. (2006). Corporate Investment with Financial Constraints: Sensitivity of Investment to Funds from Voluntary Asset Sales. Journal of Money, Credit \& Banking (Ohio State University Press), 38(2):357-374. 
Kahle, K. M. and Stulz, R. M. (2013). Access to Capital, Investment, and the Financial Crisis. Journal of Financial Economics, 110(2):280-299.

Kaplan, S. N. and Zingales, L. (1997). Do Investment-Cash Flow Sensitivities Provide Useful Measures of Financing Constraints? The Quarterly Journal of Economics, 112(1):169-215.

Kaplan, S. N. and Zingales, L. (2000). Investment-Cash Flow Sensitivities are not Valid Measures of Financing Constraints. The Quarterly Journal of Economics, 115(2):707712.

Khurana, I. K., Martin, X., and Pereira, R. (2006). Financial Development and the Cash Flow Sensitivity of Cash. Journal of Financial and Quantitative Analysis, 41(04):787808.

Lewellen, J. and Lewellen, K. (2016). Investment and Cash Flow: New Evidence. Journal of Financial and Quantitative Analysis, 51(4):1135-1164.

Lyandres, E. (2007). Costly external financing, investment timing, and investmentcash flow sensitivity. Journal of Corporate Finance, 13(5):959-980.

Machokoto, M. (2020). Do financial constraints really matter? A case of understudied African firms. International Journal of Finance and Economics, .(.):1-68.

Mody, A. and Sandri, D. (2012). The Eurozone Crisis: How Banks and Sovereigns Came to Be Joined at the Hip. Economic Policy, 27(70):199-230.

Moshirian, F., Nanda, V., Vadilyev, A., and Zhang, B. (2017). What drives investmentcash flow sensitivity around the World? An asset tangibility Perspective. Journal of Banking \& Finance, 77:1-17. 
Moyen, N. (2004). InvestmentCash Flow Sensitivities: Constrained versus Unconstrained Firms. The Journal of Finance, 59(5):2061-2092.

Pawlina, G. and Renneboog, L. (2005). Is Investment-Cash Flow Sensitivity Caused by Agency Costs or Asymmetric Information? Evidence from the UK. European Financial Management, 11(4):483-513.

Rocca, M. L., Staglian, R., and Laguir, I. (2016). Long-term investment sensitivity to cash flow and financial crisis. Applied Economics Letters, 23(6):411-414.

Wang, Q. (2015). Fixed-effect panel threshold model using Stata. Stata Journal, 15(1):121-134. Publisher: StataCorp LP.

Whited, T. M. and Wu, G. (2006). Financial Constraints Risk. The Review of Financial Studies, 19(2):531-559. 


\section{Table 1 Basic statistics}

Pane A and B present the summary statistics and correlation for all variables used, respectively. I is physical capital investment-to-total assets. $q$ is market of equity plus total debt-to-total assets (Tobin's $q$ ). CF is operating cash flow-to-total assets. Cash is cash and equivalent-to-total assets. Leverage is total debt-to-total assets. Size is the logarithm of total assets. WW Index $=-0.091 \times \frac{\text { Cash Flow }}{\text { Total Assets }}-0.062 \times$ DivDummy $+0.021 \times \frac{\text { Total debt }}{\text { Total Assets }}-0.044 \times$ Size $+0.102 \times$ IndustrySalesGrowth $-0.035 \times$ Sales Growth. The WW Index is based on Whited and Wu (2006). KZ Index $=-1.002 \times \frac{\text { Cash Flow }}{\text { Total Assets }}+0.283 \times \frac{\text { Total Debt }}{\text { Total Assets }}-39.368 \times \frac{\text { Dividends }}{\text { Total Assets }}-1.315 \times \frac{\text { Cash }}{\text { Total Assets }}$. The KZ Index is based on Kaplan and Zingales (1997). HP Index $=-0.737 \times$ Size $+0.043 \times$ Size $e^{2}-0.040 *$ Age. The HP Index is based on Hadlock and Pierce (2010). DIVTA is dividends-to-total assets. LogPPE is the logarithm of property, plant and equipment. Z-Score $=1.2 \times \frac{\text { Current Assets }- \text { Current Liabilities }}{\text { Total }}+1.4 \times$

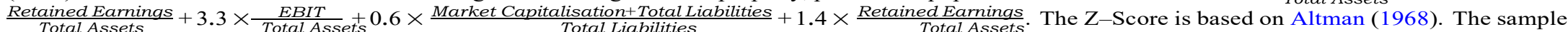
consists of listed non-utility and non-financial firms from Ivory Coast (CIV), Egypt (EGY), Ghana (GHA), Kenya (KEN), Morocco (MAR), Nigeria (NGA), South Africa percentiles. ${ }^{* * *}, * *, *$ indicate significance at the one, five, and ten percent levels, respectively.

\begin{tabular}{|c|c|c|c|c|c|c|c|c|c|c|c|c|c|}
\hline \multirow{2}{*}{$\frac{\text { Period }}{\text { Variables }}$} & \multicolumn{3}{|c|}{$2003-2012$} & \multicolumn{3}{|c|}{$2003-2007$} & \multicolumn{3}{|c|}{$2008-2012$} & \multicolumn{2}{|c|}{ Differences } & \multirow{2}{*}{$\begin{array}{l}\text { Kolmogorov } \\
\text {-Smirnov }\end{array}$} & \multirow{2}{*}{$\begin{array}{l}\text { Kruskal } \\
\text {-Wallis }\end{array}$} \\
\hline & Mean & Median & Std.dev & Mean & Median & Std.dev & Mean & Median & Std.dev & Mean & Median & & \\
\hline I & 0.081 & 0.061 & 0.080 & 0.088 & 0.065 & 0.085 & 0.077 & 0.057 & 0.077 & $-0.011 * * *$ & $-0.008 * * *$ & $0.077 * * *$ & $34.287 * * *$ \\
\hline$q$ & 0.218 & 0.203 & 0.126 & 0.248 & 0.228 & 0.129 & 0.199 & 0.179 & 0.120 & $-0.049 * * *$ & $-0.049 * * *$ & $0.202 * * *$ & $231.952^{* * *}$ \\
\hline $\mathrm{CF}$ & 0.137 & 0.102 & 0.121 & 0.144 & 0.113 & 0.123 & 0.132 & 0.098 & 0.119 & $-0.012 * * *$ & $-0.015 * * *$ & $0.078 * * *$ & $22.955^{* * *}$ \\
\hline Cash & 0.159 & 0.133 & 0.146 & 0.152 & 0.133 & 0.134 & 0.164 & 0.133 & 0.153 & $0.012 * * *$ & 0.000 & $0.048 * * *$ & 1.295 \\
\hline Leverage & 1.650 & 1.412 & 0.868 & 1.595 & 1.370 & 0.810 & 1.686 & 1.449 & 0.902 & $0.091 * * *$ & $0.079 * * *$ & $0.069 * * *$ & $7.139 * * *$ \\
\hline Size & 14.787 & 14.966 & 2.089 & 14.593 & 14.822 & 1.935 & 14.914 & 15.087 & 2.174 & $0.321 * * *$ & $0.265^{* * *}$ & $0.107 * * *$ & $33.894 * * *$ \\
\hline WW Index & -0.734 & -0.728 & 0.198 & -0.711 & -0.725 & 0.108 & -0.750 & -0.732 & 0.238 & $-0.039 * * *$ & -0.007 & $0.091 * * *$ & $12.672 * * *$ \\
\hline KZ Index & -26.558 & -4.619 & 241.219 & -13.632 & -4.502 & 33.059 & -34.924 & -4.759 & 308.176 & $-21.292 * * *$ & -0.257 & $0.056 * * *$ & 0.088 \\
\hline HP Index & -1.732 & -1.859 & 1.011 & -1.814 & -1.887 & 0.899 & -1.679 & -1.844 & 1.074 & $0.135 * * *$ & 0.043 & $0.084 * * *$ & $10.419 * * *$ \\
\hline DIVTA & 0.049 & 0.028 & 0.067 & 0.046 & 0.027 & 0.070 & 0.051 & 0.029 & 0.064 & $0.005 * * *$ & 0.002 & $0.094 * * *$ & $11.189 * * *$ \\
\hline LogPPE & 13.374 & 13.545 & 2.541 & 13.135 & 13.326 & 2.410 & 13.529 & 13.648 & 2.611 & $0.394 * * *$ & $0.322 * * *$ & $0.096^{* * *}$ & $31.701 * * *$ \\
\hline Z-Score & 4.706 & 3.986 & 3.255 & 4.642 & 4.021 & 3.007 & 4.747 & 3.955 & 3.406 & 0.105 & -0.066 & $0.046^{* * *}$ & 0.662 \\
\hline $\mathrm{N}$ & 5,352 & & & 2,108 & & & 3,244 & & & & & & \\
\hline Firms & 873 & & & & & & & & & & & & \\
\hline
\end{tabular}




\section{Table 2 Correlations}

The table presents the pairwise correlation for all variables used. The sample consists of listed non-utility and non-financial firms from Ivory Coast (CIV), Egypt (EGY), 2003 to 2012. All other variables used are defined in Table 1, and are winsorised at the lower and upper one percentiles. $* * *, * *, *$ indicate significance at the one, five, and ten percent levels, respectively.

\begin{tabular}{|c|c|c|c|c|c|c|c|c|c|c|c|c|c|}
\hline$\#$ & Variables & (1) & (2) & (3) & (4) & (5) & (6) & (7) & (8) & (9) & (10) & (11) & (12) \\
\hline (1) & I & 1 & & & & & & & & & & & \\
\hline (2) & $q$ & $0.291 * * *$ & 1 & & & & & & & & & & \\
\hline (3) & $\mathrm{CF}$ & $-0.130 * * *$ & $0.177 * * *$ & 1 & & & & & & & & & \\
\hline (4) & Cash & $0.050 * * *$ & $-0.197 * * *$ & $-0.365 * * *$ & 1 & & & & & & & & \\
\hline (5) & Leverage & $0.229 * * *$ & $0.545 * * *$ & $0.133 * * *$ & $-0.183 * * *$ & 1 & & & & & & & \\
\hline (6) & Size & $0.077 * * *$ & -0.019 & $-0.218 * * *$ & $0.147 * * *$ & $0.131 * * *$ & 1 & & & & & & \\
\hline (7) & WW Index & $-0.124 * * *$ & $-0.127 * * *$ & $0.102 * * *$ & -0.020 & $-0.188 * * *$ & $-0.548 * * *$ & 1 & & & & & \\
\hline (8) & KZ Index & $0.061 * * *$ & -0.001 & $-0.068 * * *$ & $0.040 * * *$ & 0.000 & -0.001 & -0.014 & 1 & & & & \\
\hline (9) & HP Index & $0.099 * * *$ & $-0.023 *$ & $-0.221 * * *$ & $0.154 * * *$ & $0.143 * * *$ & $0.955 * * *$ & $-0.518 * * *$ & 0.006 & 1 & & & \\
\hline (10) & DIVTA & $0.051 * * *$ & $0.445 * * *$ & $0.200 * * *$ & $-0.244 * * *$ & $0.568 * * *$ & $0.066 * * *$ & $-0.144 * * *$ & -0.021 & $0.063 * * *$ & 1 & & \\
\hline (11) & LogPPE & $0.217 * * *$ & 0.012 & $-0.304 * * *$ & $0.185 * * *$ & $0.144 * * *$ & $0.924 * * *$ & $-0.516^{* * *}$ & $0.117 * * *$ & $0.898 * * *$ & $0.082^{* * *}$ & 1 & \\
\hline (12) & Z-Score & 0.022 & $0.340^{* * *}$ & $0.299 * * *$ & $-0.379 * * *$ & $0.465 * * *$ & -0.007 & $-0.076 * * *$ & $-0.044 * * *$ & -0.018 & $0.390 * * *$ & $-0.053 * * *$ & 1 \\
\hline
\end{tabular}




\section{Table 3 The effect of the crisis on investment-cash flow sensitivity}

The table presents the estimation results of Equation (1). Crisis is a dummy variable that takes a value if one for the period 2008 - 2012 and zero otherwise. The sample (ZAF), Tunisia (TUN) and Zambia (ZMB) drawn from Datastream over the period from 2003 to 2012 . All other variables used are defined in Table 1, and are winsorised at the lower and upper one percentiles. Standard errors that are robust heteroskedasticity are reported in brackets. $* * *, * *, *$ indicate significance at the one, five, and ten percent levels, respectively.

\begin{tabular}{|c|c|c|c|c|c|c|c|c|c|}
\hline \multirow[b]{2}{*}{ Variables } & \multicolumn{3}{|c|}{ OLS } & \multicolumn{3}{|c|}{ FE } & \multicolumn{3}{|c|}{ IV } \\
\hline & (1) & (2) & (3) & (4) & (5) & (6) & (7) & (8) & (9) \\
\hline$q$ & $0.006^{* * *}$ & $0.006 * * *$ & $0.006 * * *$ & $0.015^{* * * *}$ & $0.016^{* * *}$ & $0.016^{* * *}$ & $0.029^{* * *}$ & $0.035 * * *$ & $0.035 * * *$ \\
\hline & $(0.002)$ & $(0.002)$ & $(0.002)$ & $(0.002)$ & $(0.002)$ & $(0.002)$ & $(0.005)$ & $(0.005)$ & $(0.005)$ \\
\hline $\mathrm{CF}$ & $0.149 * * *$ & $0.190 * * *$ & $0.211 * * *$ & $0.131^{* * *}$ & $0.168^{* * *}$ & $0.149 * * *$ & $0.089^{* * *}$ & $0.126^{* * *}$ & $0.116^{* * *}$ \\
\hline & $(0.015)$ & $(0.022)$ & $(0.022)$ & $(0.020)$ & $(0.028)$ & $(0.028)$ & $(0.014)$ & $(0.016)$ & $(0.016)$ \\
\hline Crisis & & $\begin{array}{l}0.021 \\
(0.016)\end{array}$ & $\begin{array}{l}0.035^{* *} \\
(0.017)\end{array}$ & & $\begin{array}{l}-0.085 \\
(0.106)\end{array}$ & $\begin{array}{l}-0.064 \\
(0.107)\end{array}$ & & $\begin{array}{l}0.138 * * * \\
(0.037)\end{array}$ & $\begin{array}{l}0.141 * * * \\
(0.037)\end{array}$ \\
\hline $\mathrm{CF} \times$ Crisis & & $-0.077 * * *$ & $-0.067 * * *$ & & $-0.073 * * *$ & $-0.062 * * *$ & & $-0.089 * * *$ & $-0.085 * * *$ \\
\hline & & $(0.023)$ & $(0.022)$ & & $(0.022)$ & $(0.022)$ & & $(0.016)$ & $(0.016)$ \\
\hline Cash & & & $-0.095 * * *$ & & & $-0.031 * * *$ & & & $-0.050^{* * * *}$ \\
\hline Leverage & & & $\begin{array}{l}(0.009) \\
0.026 * * *\end{array}$ & & & $\begin{array}{l}(0.011) \\
-0.048^{* * *}\end{array}$ & & & $\begin{array}{l}(0.014) \\
-0.006\end{array}$ \\
\hline & & & $(0.008)$ & & & $(0.016)$ & & & $(0.013)$ \\
\hline Size & & & $0.003 * * *$ & & & $-0.013^{* * *}$ & & & $-0.014 * * *$ \\
\hline Constant & $\begin{array}{l}-0.011 * \\
(0.007)\end{array}$ & $\begin{array}{l}-0.016^{* * *} \\
(0.003)\end{array}$ & $\begin{array}{l}(0.001) \\
-0.083^{*} * * \\
(0.011)\end{array}$ & $\begin{array}{l}0.023 * * * \\
(0.006)\end{array}$ & $\begin{array}{l}0.113 \\
(0.107)\end{array}$ & $\begin{array}{l}(0.005) \\
0.305^{* *} \\
(0.119)\end{array}$ & & & $(0.004)$ \\
\hline $\mathrm{N}$ & 5,352 & 5,352 & 5,352 & 5,352 & 5,352 & 5,352 & 4,372 & 4,372 & 4,372 \\
\hline $\mathrm{R}^{2}$ & 0.168 & 0.172 & 0.207 & 0.180 & 0.184 & 0.192 & 0.194 & 0.191 & 0.198 \\
\hline
\end{tabular}




\section{Table 4 Threshold effects financial constraints on investment-cash flow sensitivity}

The table presents the estimation results of Equation (1). The threshold variables are firm-size (logarithm of sales), WW Index (Whited and Wu, 2006), KZ Index (Kaplan and Zingales, 1997), HP Index (Hadlock and Pierce, 2010), dividends (dividend-to-total assets), tangibility (property, plant and equipment-to-total assets), leverage (total debt-to-total assets), and Z-Score (Altman, 1968). Crisis is a dummy variable that takes a value if one for the period 2008-2012 and zero otherwise. The sample consists Tunisia (TUN) and Zambia (ZMB) drawn from Datastream over the period from 2003 to 2012. All other variables used are defined in Table 1 , and are winsorised at the lower and upper one percentiles. Standard errors that are robust heteroskedasticity are reported in brackets. p-values are reported in parentheses. $* * *, * *, *$ indicate significance at the one, five, and ten percent levels, respectively.

\begin{tabular}{|c|c|c|c|c|c|c|c|c|}
\hline Financial Constraint & Size & WW Index & KZ Index & HP Index & Dividends & Tangibility & Leverage & Z-Score \\
\hline Variables & (1) & (2) & (3) & (4) & (5) & (6) & (7) & (8) \\
\hline
\end{tabular}

\section{Panel A: The effects of financial constraints}

\begin{tabular}{|c|c|c|c|c|c|c|c|c|}
\hline $\begin{array}{l}\mathrm{CF}^{\mathrm{C}} \\
\mathrm{CF}^{\mathrm{U}}\end{array}$ & $\begin{array}{l}0.145 * * * \\
(0.016) \\
0.090 * * * \\
(0.015)\end{array}$ & $\begin{array}{l}0.191 * * * \\
(0.017) \\
0.089 * * * \\
(0.014)\end{array}$ & $\begin{array}{l}0.152 * * * \\
(0.014) \\
0.055 * * * \\
(0.015)\end{array}$ & $\begin{array}{l}0.237 * * * \\
(0.025) \\
0.101 * * * \\
(0.014)\end{array}$ & $\begin{array}{l}0.157 * * * \\
(0.014) \\
0.061 * * * \\
(0.015)\end{array}$ & $\begin{array}{l}0.077 * * * \\
(0.015) \\
0.151 * * * \\
(0.015)\end{array}$ & $\begin{array}{l}0.226 * * * \\
(0.017) \\
0.088 * * * \\
(0.013)\end{array}$ & $\begin{array}{l}0.037 * \\
(0.020) \\
0.127 * * * \\
(0.014)\end{array}$ \\
\hline $\begin{array}{l}\text { Controls } \\
\mathrm{N} \\
\mathrm{R}^{2} \\
\text { Threshold } \\
\text { Threshold (\%) } \\
\text { Probability (p-value) } \\
\mathrm{CF}^{\mathbf{C}}=\mathrm{CF}^{\mathbf{U}}\end{array}$ & $\begin{array}{l}\text { Yes } \\
2,730 \\
0.148 \\
14.920 \\
36 \\
{[0.052]} \\
{[0.000]}\end{array}$ & $\begin{array}{l}\text { Yes } \\
2,730 \\
0.162 \\
0.714 \\
31 \\
{[0.000]} \\
{[0.000]}\end{array}$ & $\begin{array}{l}\text { Yes } \\
2,730 \\
0.166 \\
6.283 \\
55 \\
{[0.000]} \\
{[0.000]}\end{array}$ & $\begin{array}{l}\text { Yes } \\
2,730 \\
0.155 \\
0.695 \\
16 \\
{[0.000]} \\
{[0.000]}\end{array}$ & $\begin{array}{l}\text { Yes } \\
2,730 \\
0.170 \\
0.040 \\
60 \\
{[0.000]} \\
{[0.000]}\end{array}$ & $\begin{array}{l}\text { Yes } \\
2,730 \\
0.153 \\
14.270 \\
52 \\
{[0.002]} \\
{[0.000]}\end{array}$ & $\begin{array}{l}\text { Yes } \\
2,730 \\
0.181 \\
-0.194 \\
33 \\
{[0.000]} \\
{[0.000]}\end{array}$ & $\begin{array}{l}\text { Yes } \\
2,730 \\
0.153 \\
3.041 \\
18 \\
{[0.000]} \\
{[0.000]}\end{array}$ \\
\hline
\end{tabular}

Panel B: The effects of financial constraints and the crisis

\begin{tabular}{|c|c|c|c|c|c|c|c|c|}
\hline $\mathrm{CF}^{\mathrm{C}}$ & $0.107 * * *$ & $0.209 * * *$ & $0.204 * * *$ & $0.335 * * *$ & $0.206 * * *$ & $0.097 * * *$ & $0.280 * * *$ & $0.084 * * *$ \\
\hline $\mathrm{CF}^{0} \times$ Crisis & $\begin{array}{l}(0.017) \\
-0.055^{*} * *\end{array}$ & $\begin{array}{l}(0.018) \\
-0.056 * * *\end{array}$ & $(0.016)$ & $\begin{array}{l}(0.029) \\
-0.191 * * *\end{array}$ & $(0.017)$ & $(0.016)$ & $(0.019)$ & $(0.024)$ \\
\hline & $(0.020)$ & $(0.021)$ & $(0.021)$ & $(0.030)$ & $\begin{array}{l}-0.125 \\
(0.023)\end{array}$ & $\begin{array}{l}-0.063^{* * *} \\
(0.018)\end{array}$ & $\begin{array}{l}-0.142^{* * *} \\
(0.021)\end{array}$ & $\begin{array}{l}-0.287^{* * * *} \\
(0.049)\end{array}$ \\
\hline $\mathrm{CF}^{\mathrm{U}}$ & $0.171^{*} * *$ & $0.106^{* * *}$ & $0.069 * * *$ & $0.126^{* * *}$ & $0.081 * * *$ & $0.195^{* * *}$ & $0.106^{* * *}$ & $0.153 * * *$ \\
\hline $\mathrm{CF}^{\mathrm{U}} \times$ Crisis & $\begin{array}{l}(0.017) \\
-0.082 * * * \\
(0.019)\end{array}$ & $\begin{array}{l}(0.016) \\
-0.039 * * \\
(0.018)\end{array}$ & $\begin{array}{l}(0.016) \\
-0.041 * * \\
(0.017)\end{array}$ & $\begin{array}{l}(0.015) \\
-0.056 * * * \\
(0.017)\end{array}$ & $\begin{array}{l}(0.016) \\
-0.037^{* *} \\
(0.017)\end{array}$ & $\begin{array}{l}(0.018) \\
-0.097 * * * \\
(0.021)\end{array}$ & $\begin{array}{l}(0.015) \\
-0.041^{* *} \\
(0.017)\end{array}$ & $\begin{array}{l}(0.015) \\
-0.070^{* * *} \\
(0.017)\end{array}$ \\
\hline Controls & Yes & Yes & Yes & Yes & Yes & Yes & Yes & Yes \\
\hline & 2,730 & 2,730 & 2,730 & 2,730 & 2,730 & 2,730 & 2,730 & 2,730 \\
\hline $\mathrm{R}^{2}$ & 0.152 & 0.165 & 0.184 & 0.168 & 0.182 & 0.161 & 0.198 & 0.165 \\
\hline Threshold & 14.870 & 0.714 & 6.283 & 0.695 & 0.040 & 14.270 & -0.194 & 2.885 \\
\hline Threshold (\%) & 35 & 31 & & & & 52 & & \\
\hline Probability (p-value) & {$[0.107]$} & {$[0.000]$} & {$[0.000]$} & {$[0.000]$} & {$[0.000]$} & {$[0.000]$} & {$[0.000]$} & {$[0.000]$} \\
\hline $\mathrm{CF}^{\mathbf{C}}=\mathrm{CF}^{\mathbf{U}}$ & {$[0.000]$} & {$[0.000]$} & {$[0.000]$} & {$[0.000]$} & {$[0.000]$} & {$[0.000]$} & {$[0.000]$} & {$[0.000]$} \\
\hline $\begin{array}{l}\mathrm{CF}^{\mathrm{C}} \times \text { Crisis }=\mathrm{CF}^{\mathrm{U}} \times \text { Crisis } \\
\mathrm{CF}^{\mathrm{C}}+\mathrm{CF}^{\mathrm{C}} \times \text { Crisis }\end{array}$ & {$[0.096]$} & {$[0.302]$} & {$[0.000]$} & {$[0.000]$} & {$[0.000]$} & {$[0.030]$} & {$[0.000]$} & {$[0.000]$} \\
\hline$=\mathrm{CF}^{\mathrm{U}}+\mathrm{CF}^{\mathrm{U}} \times$ Crisis & {$[0.055]$} & {$[0.000]$} & {$[0.014]$} & {$[0.004]$} & {$[0.014]$} & {$[0.000]$} & {$[0.000]$} & {$[0.000]$} \\
\hline
\end{tabular}

Note: For brevity, the table only reports the main variables of interest. 


\section{Table 5 Factors affecting investment-cash flow sensitivity}

The table presents the estimation results of Equation (1). Crisis is a dummy variable that takes a value if one for the period $2008-2012$ and zero otherwise. R\&D is research and development-to-total assets. PPE is property, plant and equipment-to-total assets. Trend is the time trend variable. Med-I is the median industrial investment in each year. SMGDP is the stock market capitalisation-to-GDP and PDCGDP is the domestic credit-to-GDP. SMGDP and PDCGDP are from World Bank Ivory Coast (CIV), Egypt (EGY), Ghana (GHA), Kenya (KEN), Morocco (MAR), Nigeria (NGA), South Africa (ZAF), Tunisia (TUN) and Zambia (ZMB) drawn from Datastream over the period from 2003 to 2012. All other variables used are defined in Table 1, and are winsorised at the lower and upper one percentiles. Standard errors that are robust heteroskedasticity are reported in brackets. $* * *, * *, *$ indicate significance at the one, five, and ten percent levels, respectively.

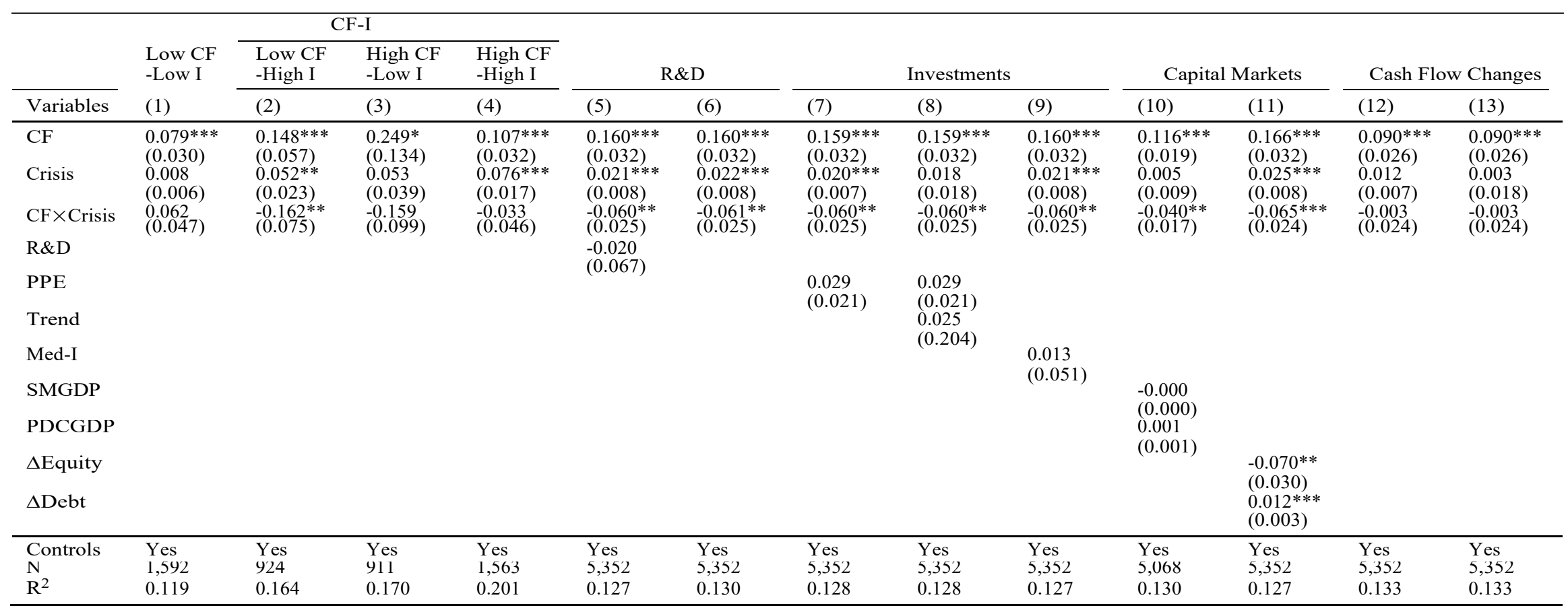




\section{Table 6 Time series estimates of investment-cash flow sensitivity}

The table presents the estimation results of Equation (1) using 5-year rolling regressions over the sample period for all firms, and the unbalanced and balanced samples. South Africa (ZAF), Tunisia (TUN) and Zambia (ZMB) drawn from Datastream over the period from 2003 to 2012 . All other variables used are defined in Table 1 , and are winsorised at the lower and upper one percentiles. Standard errors that are robust heteroskedasticity are reported in brackets. ***,**,* indicate significance at the one, five, and ten percent levels, respectively.

\begin{tabular}{|c|c|c|c|c|c|c|c|c|c|c|c|c|}
\hline \multirow[b]{2}{*}{ Period } & \multicolumn{4}{|c|}{ Full sample } & \multicolumn{4}{|c|}{ Unbalanced sample } & \multicolumn{4}{|c|}{ Balanced sample } \\
\hline & $\mathrm{CF}$ & $\mathrm{SE}$ & $\mathrm{R}^{2}$ & $\mathrm{~N}$ & $\mathrm{CF}$ & $\mathrm{SE}$ & $\mathrm{R}^{2}$ & $\mathrm{~N}$ & $\mathrm{CF}$ & SE & $\mathrm{R}^{2}$ & $\mathrm{~N}$ \\
\hline Variables & (1) & (2) & (3) & (4) & (5) & (6) & (7) & (8) & (9) & (10) & (11) & (12) \\
\hline $\begin{array}{l}2003-2007 \\
2004-2008 \\
2005-2009 \\
2006-2010 \\
2007-2011 \\
2008-2012\end{array}$ & $\begin{array}{l}0.188 * * * \\
0.180 * * * \\
0.132 * * * \\
0.054 * * \\
0.056 * * * \\
0.047 * * *\end{array}$ & $\begin{array}{l}(0.058) \\
(0.057) \\
(0.040) \\
(0.021) \\
(0.020) \\
(0.018)\end{array}$ & $\begin{array}{l}0.711 \\
0.725 \\
0.703 \\
0.706 \\
0.688 \\
0.695\end{array}$ & $\begin{array}{l}2,108 \\
2,297 \\
2,556 \\
2,876 \\
3,145 \\
3,244 \\
\end{array}$ & $\begin{array}{l}0.204 * * * \\
0.236^{* * *} \\
0.162 * * * \\
0.078^{*} \\
0.093^{* * *} \\
0.080^{* * *}\end{array}$ & $\begin{array}{l}(0.064) \\
(0.088) \\
(0.046) \\
(0.041) \\
(0.030) \\
(0.024)\end{array}$ & $\begin{array}{l}0.814 \\
0.795 \\
0.753 \\
0.718 \\
0.700 \\
0.707\end{array}$ & $\begin{array}{l}743 \\
932 \\
1,191 \\
1,511 \\
1,780 \\
1,879 \\
\end{array}$ & $\begin{array}{l}0.175^{* *} \\
0.140^{* *} \\
0.101^{*} \\
0.027 \\
0.019 \\
0.032\end{array}$ & $\begin{array}{l}(0.084) \\
(0.071) \\
(0.056) \\
(0.017) \\
(0.020) \\
(0.024)\end{array}$ & $\begin{array}{l}0.633 \\
0.656 \\
0.640 \\
0.698 \\
0.676 \\
0.686\end{array}$ & $\begin{array}{l}1,365 \\
1,365 \\
1,365 \\
1,365 \\
1,365 \\
1,365\end{array}$ \\
\hline $2003-2012$ & $0.128 * * *$ & $(0.025)$ & 0.613 & 5,352 & $0.138 * * *$ & $(0.029)$ & 0.659 & 2,622 & $0.114 * * *$ & $(0.038)$ & 0.549 & 2,730 \\
\hline
\end{tabular}




\section{Table 7 Alternatives estimations of investment-cash flow sensitivity}

The table presents the estimation results of Equation (1) using the GMM estimator of Erickson and Whited (2000, 2002) (GMM5), instrumental variables GMM (IV-GMM) (Baum et al., 2003), dynamic fractional dependent variables (DPF) (Elsas et al., 2013; Elsas and Florysiak, 2015), difference GMM (DIF-GMM) (Arellano and Bond, 1991) and system South A frica (ZAF), Tus (TUN) and Zambia (ZMB) drawn from South Afre (ZAF), Tus (TUN) a Za are winsorised at the lower and upper one percentiles. $\tau$ is an index or measuent quality or Tobin's $q$ which ranges between zero and one, with zero indicating a poor indicate significance at the one, five, and ten percent levels, respectively.

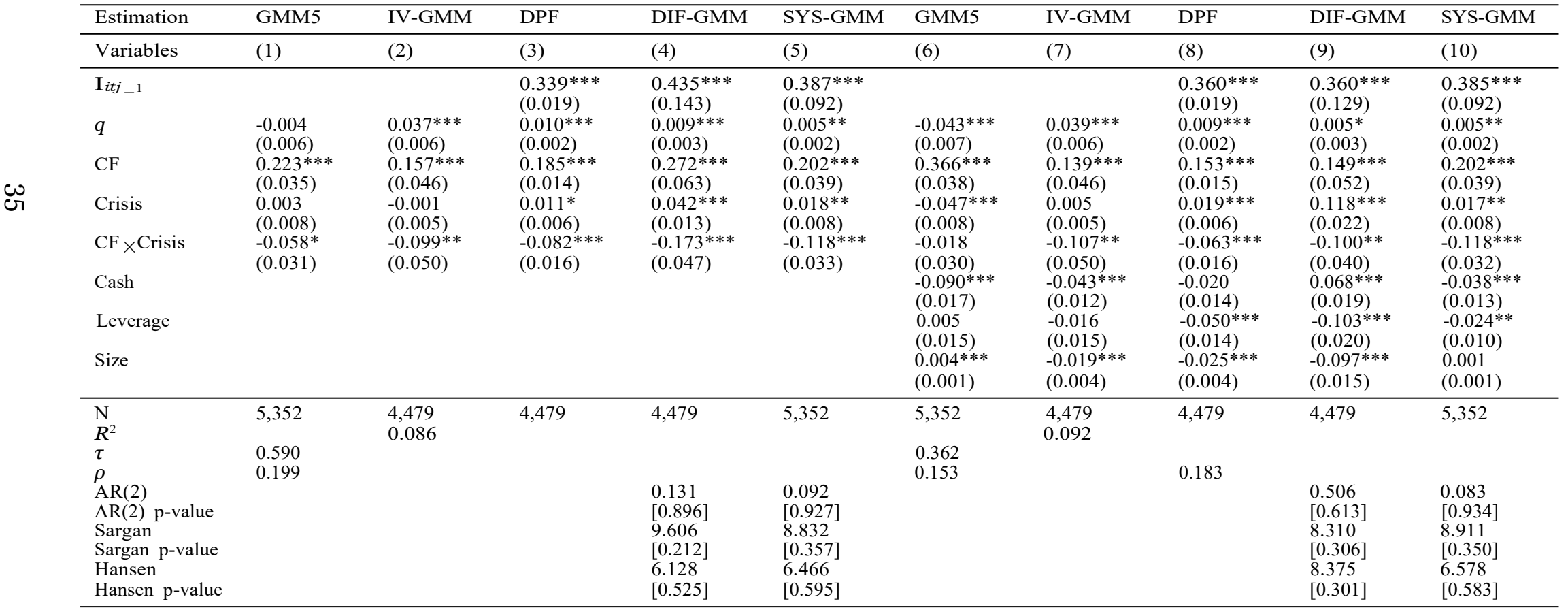




\section{Appendix A Alternative estimates of the effects of financial constraints on investment-cash flow sensitivity}

The table presents the estimation results of Equation (1). Crisis is a dummy variable that takes a value if one for the period 2008 - 2012 and zero otherwise. FCD is a dummy variable that takes a value if one if a firm is categorised as constrained and zero otherwise. A firm is categorised as being constrained if it is below the median of size (logarithm of sales), dividends (dividend-to-total assets), profitability (profit-to-total assets) and tangibility (total debt-to-total assets), and above the median of WW Index (Whited and Wu, 2006) and leverage (total debt-to-total assets). WW Index $=-0.091 \times \frac{\text { Cash Flow }}{\text { Assets }}-0.062 \times$ DivDummy $+0.021 \times \frac{\text { Total debt }}{\text {. The sample }}$ consists of listed non-utility and non-financial firms from Ivory Coast (CIV), Egypt (EGY), Ghana (GHA), Kenya (KEN), Morocco (MAR), Nigeria (NGA), South Africa (1) All other variables used are defined in Table 1 and are winsorised 等 ten percent levels, respectively.

\begin{tabular}{|c|c|c|c|c|c|c|c|c|}
\hline Financial Constraint & Size & WW Index & KZ Index & HP Index & Dividends & Tangibility & Leverage & Z-Score \\
\hline Variables & (1) & (2) & (3) & (4) & (5) & (6) & (7) & (8) \\
\hline $\mathrm{CF}$ & $\begin{array}{l}0.174 * * * \\
(0.041)\end{array}$ & $\begin{array}{l}0.131 * * * \\
(0.018)\end{array}$ & $\begin{array}{l}0.090 * * * \\
(0.019)\end{array}$ & $\begin{array}{l}0.175 * * * \\
(0.026)\end{array}$ & $\begin{array}{l}0.141 * * * \\
(0.038)\end{array}$ & $\begin{array}{l}0.165^{* * *} \\
(0.039)\end{array}$ & $\begin{array}{l}0.103 * * * \\
(0.019)\end{array}$ & $\begin{array}{l}0.150 * * * \\
(0.037)\end{array}$ \\
\hline Crisis & $\begin{array}{l}0.022 * * \\
(0.009)\end{array}$ & $\begin{array}{l}0.015^{* *} \\
(0.007)\end{array}$ & $\begin{array}{l}0.016^{* *} \\
(0.006)\end{array}$ & $\begin{array}{l}0.023^{* * * *} \\
(0.008)\end{array}$ & $\begin{array}{l}0.024^{* * *} \\
(0.008)\end{array}$ & $\begin{array}{l}0.019^{* * *} \\
(0.009)\end{array}$ & $\begin{array}{l}0.017 * * * \\
(0.006)\end{array}$ & $\begin{array}{l}0.020^{* *} \\
(0.008)\end{array}$ \\
\hline $\mathrm{CF} \times$ Crisis & $\begin{array}{l}-0.073^{* *} \\
(0.034)\end{array}$ & $\begin{array}{l}-0.039 * * \\
(0.018)\end{array}$ & $\begin{array}{l}-0.030^{*} \\
(0.018)\end{array}$ & $\begin{array}{l}-0.063 * * \\
(0.028)\end{array}$ & $\begin{array}{l}-0.073 * * \\
(0.029)\end{array}$ & $\begin{array}{l}-0.059^{*} \\
(0.031)\end{array}$ & $\begin{array}{l}-0.053^{* * *} \\
(0.017)\end{array}$ & $\begin{array}{l}-0.051^{*} \\
(0.028)\end{array}$ \\
\hline $\mathrm{F}(\mathrm{V})$ & $\begin{array}{l}\text { U.viU } \\
(0.009)\end{array}$ & $\begin{array}{l}-U .014 \\
(0.012)\end{array}$ & $\begin{array}{l}-U .0 \leq L^{\cdots *} \\
(0.013)\end{array}$ & $\begin{array}{l}\text { U.U11 } \\
(0.013)\end{array}$ & $\begin{array}{l}-U . U 08 \\
(0.009)\end{array}$ & $\begin{array}{l}\text { u.uox } \\
(0.009)\end{array}$ & $\begin{array}{l}-U . U 5 L^{\cdots *} \\
(0.015)\end{array}$ & $\begin{array}{l}-0.014 \\
(0.010)\end{array}$ \\
\hline $\mathrm{CF} \times \mathrm{FCD}$ & $\begin{array}{l}-0.036 \\
(0.042)\end{array}$ & $\begin{array}{l}0.081 \\
(0.053)\end{array}$ & $\begin{array}{l}0.196^{* * *} \\
(0.064)\end{array}$ & $\begin{array}{l}-0.035 \\
(0.057)\end{array}$ & $\begin{array}{l}0.076 \\
(0.047)\end{array}$ & $\begin{array}{l}-0.017 \\
(0.042)\end{array}$ & $\begin{array}{l}0.195 * * * \\
(0.064)\end{array}$ & $\begin{array}{l}0.108^{* *} \\
(0.049)\end{array}$ \\
\hline Crisis $\times$ FCD & $\begin{array}{l}-0.036 \\
(0.042)\end{array}$ & $\begin{array}{l}0.081 \\
(0.053)\end{array}$ & $\begin{array}{l}0.196^{* * *} \\
(0.064)\end{array}$ & $\begin{array}{l}-0.035 \\
(0.057)\end{array}$ & $\begin{array}{l}0.076 \\
(0.047)\end{array}$ & $\begin{array}{l}-0.017 \\
(0.042)\end{array}$ & $\begin{array}{l}0.195 * * * \\
(0.064)\end{array}$ & $\begin{array}{l}0.108^{* *} \\
(0.049)\end{array}$ \\
\hline $\mathrm{CF} \times$ Crisis $\times$ FCD & $\begin{array}{l}0.033 \\
(0.042)\end{array}$ & $\begin{array}{l}-0.064 \\
(0.057)\end{array}$ & $\begin{array}{l}-0.136^{* *} \\
(0.064)\end{array}$ & $\begin{array}{l}0.011 \\
(0.056)\end{array}$ & $\begin{array}{l}0.006 \\
(0.047)\end{array}$ & $\begin{array}{l}0.003 \\
(0.044)\end{array}$ & $\begin{array}{l}-0.059 \\
(0.063)\end{array}$ & $\begin{array}{l}-0.130^{* *} \\
(0.049)\end{array}$ \\
\hline $\begin{array}{l}\text { Controls } \\
\mathrm{N} \\
\mathrm{R}^{2}\end{array}$ & $\begin{array}{l}\text { Yes } \\
5,352 \\
0,128\end{array}$ & $\begin{array}{l}\text { Yes } \\
5,352 \\
0,131\end{array}$ & $\begin{array}{l}\text { Yes } \\
5,352 \\
0,147\end{array}$ & $\begin{array}{l}\text { Yes } \\
5,352 \\
0128\end{array}$ & $\begin{array}{l}\text { Yes } \\
5,352 \\
0,133\end{array}$ & $\begin{array}{l}\text { Yes } \\
5,352 \\
0,128\end{array}$ & $\begin{array}{l}\text { Yes } \\
5,352 \\
0,153\end{array}$ & $\begin{array}{l}\text { Yes } \\
5,352 \\
0,136\end{array}$ \\
\hline
\end{tabular}

Note: For brevity, the table only reports the main variables of interest. 


\section{Appendix B Sub-period analyses of the threshold effects of financial constraints}

The table presents the estimation results of Equation (1). Crisis is a dummy variable that takes a value if one for the period $2008-2012$ and zero otherwise. The ( sample consists of listed non-utility and non-financial firms from Ivory Coast (CIV), Egypt (EGYY), Ghana (GHA), Kenya (KEN), Morocco (MAR), Nigeria (NGA), South Africa (ZAF), Tunisia (TUN) and Zambia (ZMB) drawn from Datastream over the period from 2003 to 2012. All other variables used are defined in Table 1, and are winsorised at the lower and upper one percentiles. Standard errors that are robust heteroskedasticity are reported in brackets. $p$-values are reported in parentheses. $* * *$, $*$, indicate significance at the one, five, and ten percent levels, respectively.

\begin{tabular}{|c|c|c|c|c|c|c|c|c|}
\hline Financial Constraint & Size & WW Index & KZ Index & HP Index & Dividends & Tangibility & Leverage & Z-Score \\
\hline Variables & (1) & $(2)$ & (3) & (4) & $(5)$ & $(6)$ & (7) & $(8)$ \\
\hline \multicolumn{9}{|c|}{ Panel A: 2003-2007 (Pre-crisis) } \\
\hline $\begin{array}{l}\mathrm{CF}^{\mathbf{C}} \\
\mathrm{CF}^{\mathbf{U}}\end{array}$ & $\begin{array}{l}0.258 * * * \\
(0.021) \\
0.029 \\
(0.026)\end{array}$ & $\begin{array}{l}0.278 * * * \\
(0.023) \\
0.125 * * * \\
(0.021)\end{array}$ & $\begin{array}{l}0.294 * * * \\
(0.024) \\
0.135 * * * \\
(0.020) \\
\end{array}$ & $\begin{array}{l}0.003 \\
(0.028) \\
0.261 * * * \\
(0.022) \\
\end{array}$ & $\begin{array}{l}0.227 * * * \\
(0.020) \\
0.091 * * * \\
(0.022) \\
\end{array}$ & $\begin{array}{l}0.244 * * * \\
(0.022) \\
0.062 * * \\
(0.026)\end{array}$ & $\begin{array}{l}0.369 * * * \\
(0.025) \\
0.143 * * * \\
(0.019)\end{array}$ & $\begin{array}{l}0.077 * * * \\
(0.027) \\
0.205 * * * \\
(0.020)\end{array}$ \\
\hline $\begin{array}{l}\text { Controls } \\
\mathrm{N} \\
\mathrm{R}^{2} \\
\text { Threshold } \\
\text { Threshold (\%) } \\
\text { Probability (p-value) } \\
\mathrm{CF}^{\mathbf{C}}=\mathrm{CF}^{\mathbf{U}}\end{array}$ & $\begin{array}{l}\text { Yes } \\
1,630 \\
0.225 \\
15.340 \\
56 \\
{[0.000]} \\
{[0.000]} \\
\end{array}$ & $\begin{array}{l}\text { Yes } \\
1,630 \\
0.220 \\
0.714 \\
41 \\
{[0.000]} \\
{[0.000]} \\
\end{array}$ & $\begin{array}{l}\text { Yes } \\
1,630 \\
0.218 \\
1.588 \\
27 \\
{[0.000]} \\
{[0.000]} \\
\end{array}$ & $\begin{array}{l}\text { Yes } \\
1,630 \\
0.222 \\
1.577 \\
38 \\
{[0.000]} \\
{[0.000]} \\
\end{array}$ & $\begin{array}{l}\text { Yes } \\
1,630 \\
0.223 \\
0.040 \\
64 \\
{[0.000]} \\
{[0.000]} \\
\end{array}$ & $\begin{array}{l}\text { Yes } \\
1,630 \\
0.210 \\
14.520 \\
69 \\
{[0.000]} \\
{[0.000]} \\
\end{array}$ & $\begin{array}{l}\text { Yes } \\
1,630 \\
0.256 \\
-0.194 \\
32 \\
{[0.000]} \\
{[0.000]} \\
\end{array}$ & $\begin{array}{l}\text { Yes } \\
1,630 \\
0.198 \\
3.055 \\
24 \\
{[0.000]} \\
{[0.000]} \\
\end{array}$ \\
\hline \multicolumn{9}{|c|}{ Panel B: 2008-2012 (Crisis) } \\
\hline $\begin{array}{l}\mathrm{CF}^{\mathbf{C}} \\
\mathrm{CF}^{\mathbf{U}}\end{array}$ & $\begin{array}{l}0.182 * * * \\
(0.027) \\
-0.007 \\
(0.018)\end{array}$ & $\begin{array}{l}0.080 * * * \\
(0.024) \\
0.017 \\
(0.018)\end{array}$ & $\begin{array}{l}0.010 \\
(0.024) \\
0.037 * * \\
(0.018)\end{array}$ & $\begin{array}{l}-0.016 \\
(0.019) \\
0.145^{*} * * \\
(0.024)\end{array}$ & $\begin{array}{l}0.073 * * * \\
(0.021) \\
0.021 \\
(0.018)\end{array}$ & $\begin{array}{l}0.171 * * * \\
(0.031) \\
0.009 \\
(0.018)\end{array}$ & $\begin{array}{l}0.141 * * * \\
(0.024) \\
0.013 \\
(0.017)\end{array}$ & $\begin{array}{l}-0.109 * * * \\
(0.026) \\
0.072 * * * \\
(0.018)\end{array}$ \\
\hline $\begin{array}{l}\text { Controls } \\
\mathrm{N} \\
\mathrm{R}^{2} \\
\text { Threshold } \\
\text { Threshold (\%) } \\
\text { Probability (p-value) } \\
\mathrm{CF}^{\mathbf{C}}=\mathrm{CF}^{\mathbf{U}}\end{array}$ & $\begin{array}{l}\text { Yes } \\
2,180 \\
0.138 \\
14.490 \\
34 \\
{[0.000]} \\
{[0.000]}\end{array}$ & $\begin{array}{l}\text { Yes } \\
2,180 \\
0.115 \\
0.734 \\
41 \\
{[0.205]} \\
{[0.006]}\end{array}$ & $\begin{array}{l}\text { Yes } \\
2,180 \\
0.113 \\
1.633 \\
28 \\
{[0.150]} \\
{[0.136]}\end{array}$ & $\begin{array}{l}\text { Yes } \\
2,180 \\
0.134 \\
1.942 \\
62 \\
{[0.000]} \\
{[0.000]}\end{array}$ & $\begin{array}{l}\text { Yes } \\
2,180 \\
0.117 \\
0.023 \\
36 \\
{[0.049]} \\
{[0.001]}\end{array}$ & $\begin{array}{l}\text { Yes } \\
2,180 \\
0.127 \\
12.060 \\
20 \\
{[0.001]} \\
{[0.000]}\end{array}$ & $\begin{array}{l}\text { Yes } \\
2,180 \\
0.133 \\
-0.217 \\
28 \\
{[0.000]} \\
{[0.000]}\end{array}$ & $\begin{array}{l}\text { Yes } \\
2,180 \\
0.137 \\
2.891 \\
18 \\
{[0.000]} \\
{[0.000]}\end{array}$ \\
\hline
\end{tabular}




\section{Appendix C Alternative crisis periods, other models and regional samples}

The table presents the estimation results of Equation (1). For Columns (1) - (2), the Crisis dummy variable that takes a value if one for the period 2007-2009 and zero otherwise. For Columns (3) - (4), the Crisis dummy variable that takes a value if one for the period 2008-2009 and zero otherwise. For Columns (5) - (7), the Crisis dummy variable that takes a value if one for the period $2008-2012$ and zero otherwise. Div-Model includes dividends $(D I V T A)$ as an additional determinant of investment in Equation (1). Sub-Saharan Africa (SSA) is composed of firms in Ivory Coast, Ghana, Kenya, Nigeria, South Africa and Zambia. North Africa (NA) is composed of firms in Egypt, Morocco and Tunisia. The sample consists of listed non-utility and non-financial firms from Ivory Coast (CIV), Egypt (EGY), Ghana (GHA), Kenya (KEN), Morocco (MAR), Nigeria (NGA), South Africa (ZAF), Tunisia (TUN) and Zambia (ZMB) drawn from Datastream over the period from 2003 to 2012 . All other variables used are defined in Table 1 , and are winsorised at the lower and upper one percentiles. Standard errors that are robust heteroskedasticity are reported in brackets. $* * *, * *, *$ indicatesignificance at the one, five, and ten percent levels, respectively.

\begin{tabular}{|c|c|c|c|c|c|c|c|}
\hline \multirow{3}{*}{$\begin{array}{l}\text { Sample } \\
\text { Variables }\end{array}$} & \multicolumn{4}{|c|}{$2003-2009$} & \multicolumn{3}{|c|}{$2003-2012$} \\
\hline & \multicolumn{2}{|c|}{$2007 \geq$ Crisis $\leq 2009$} & \multicolumn{2}{|c|}{$2008 \geq$ Crisis $\leq 2009$} & \multirow{2}{*}{$\frac{\text { Div-Model }}{(5)}$} & \multirow{2}{*}{$\frac{\mathrm{SSA}}{(6)}$} & \multirow{2}{*}{$\frac{\mathrm{NA}}{(7)}$} \\
\hline & (1) & (2) & (3) & (4) & & & \\
\hline \multirow[t]{2}{*}{$q$} & $0.023 * * *$ & $0.023 * * *$ & $0.028 * * *$ & $0.029 * * *$ & $0.015 * * *$ & $0.018 * * *$ & 0.004 \\
\hline & $(0.003)$ & $(0.003)$ & $(0.003)$ & $(0.003)$ & $(0.002)$ & $(0.003)$ & $(0.004)$ \\
\hline \multirow[t]{2}{*}{$\mathrm{CF}$} & $0.165 * * *$ & $0.146^{* * *}$ & $0.162 * * *$ & $0.150 * * *$ & $0.149 * * *$ & $0.114 * * *$ & $0.574 * *$ \\
\hline & $(0.027)$ & $(0.026)$ & $(0.030)$ & $(0.029)$ & $(0.028)$ & $(0.019)$ & $(0.225)$ \\
\hline Crisis & $\begin{array}{l}0.089 * * * \\
(0.016)\end{array}$ & $\begin{array}{l}0.087 * * * \\
(0.017)\end{array}$ & $\begin{array}{l}-0.035 * * * \\
(0.007)\end{array}$ & $\begin{array}{l}-0.030 * * * \\
(0.008)\end{array}$ & $\begin{array}{l}-0.065 \\
(0.107)\end{array}$ & $\begin{array}{l}-0.076 \\
(0.107)\end{array}$ & $\begin{array}{l}0.149 * * * \\
(0.038)\end{array}$ \\
\hline $\mathrm{CF} \times$ Crisis & $-0.085 * * *$ & $-0.073 * * *$ & $-0.077 * *$ & $-0.070 * *$ & $-0.063 * * *$ & $-0.039 * *$ & $-0.386^{* *}$ \\
\hline & $(0.024)$ & $(0.025)$ & $(0.031)$ & $(0.033)$ & $(0.022)$ & $(0.017)$ & $(0.162)$ \\
\hline Cash & & -0.022 & & $-0.037 * *$ & $-0.031 * * *$ & $-0.043 * * *$ & $0.078 *$ \\
\hline \multirow[t]{2}{*}{ Leverage } & & $-0.070 * * *$ & & $\begin{array}{l}(0.018) \\
-0.083 * * *\end{array}$ & $-0.048^{* * *}$ & $-0.044 * * *$ & $\begin{array}{l}(0.046) \\
-0.050\end{array}$ \\
\hline & & $(0.024)$ & & $(0.026)$ & $(0.016)$ & $(0.016)$ & $(0.056)$ \\
\hline \multirow[t]{2}{*}{ Size } & & $-0.018 * * *$ & & -0.005 & $-0.013 * *$ & $-0.009 *$ & $-0.075 * * *$ \\
\hline & & $(0.006)$ & & $(0.007)$ & $(0.005)$ & $(0.005)$ & $(0.016)$ \\
\hline Dividends & & & & & $\begin{array}{l}0.010 \\
(0.024)\end{array}$ & & \\
\hline $\mathrm{N}$ & 2,601 & 2,601 & 2,488 & 2,488 & 5,352 & 4,538 & 814 \\
\hline $\mathrm{R}^{2}$ & 0.318 & 0.329 & 0.314 & 0.322 & 0.192 & 0.175 & 0.392 \\
\hline
\end{tabular}




\section{Online Appendices}

Not For Publication 


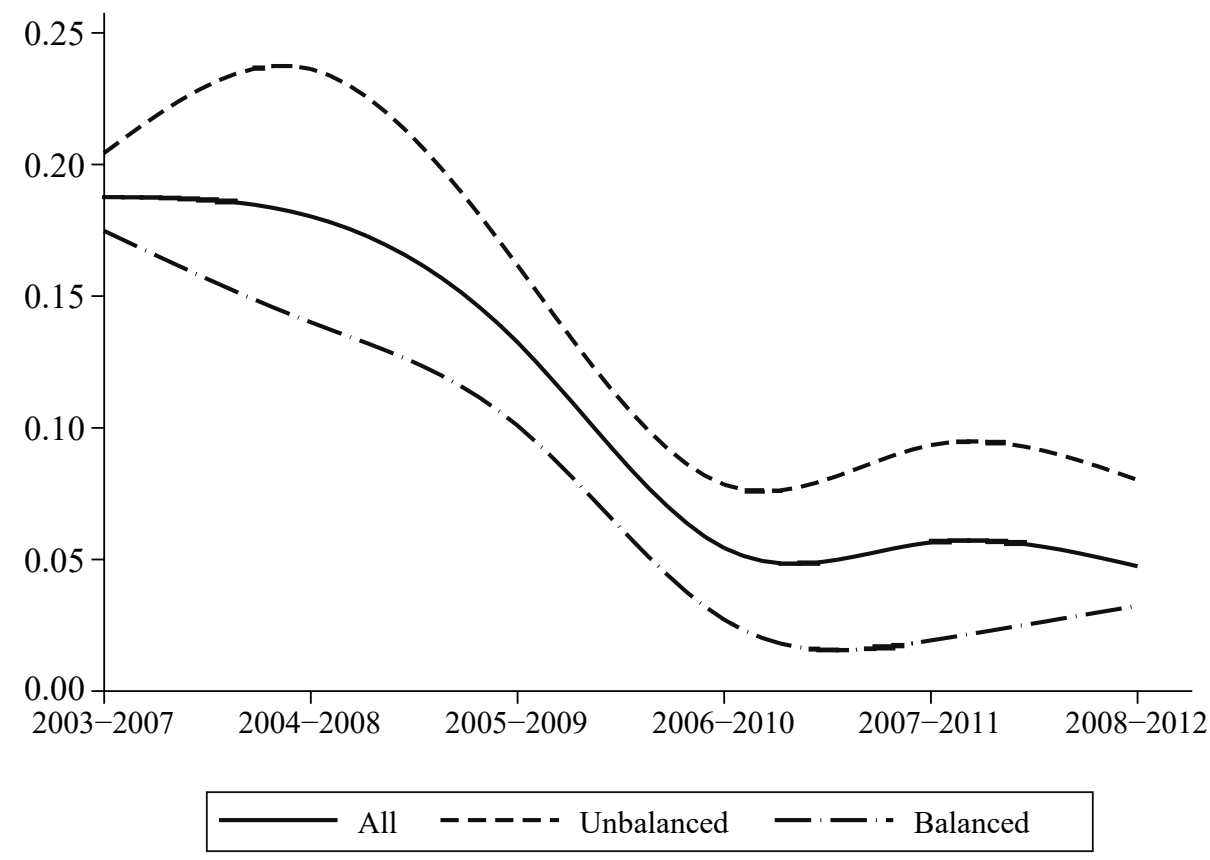

Figure A.1 The evolution of investment-cash flow sensitivity

The figure plots estimates of investment-cash flow sensitivity from Equation (1) using 5-year rolling regressions for all firms (All), unbalanced sample (Unbalanced) and balanced sample (Balanced) over the sample period. The sample consists of listed non-utility and non-financial firms from Ivory Coast (CIV), Egypt (EGY), Ghana (GHA), Kenya (KEN), Morocco (MAR), Nigeria (NGA), South Africa (ZAF), Tunisia (TUN) and Zambia (ZMB) drawn from Datastream over the period from 2003 to 2012. All other variables used are defined in Table 1, and are winsorised at the lower and upper one percentiles. 


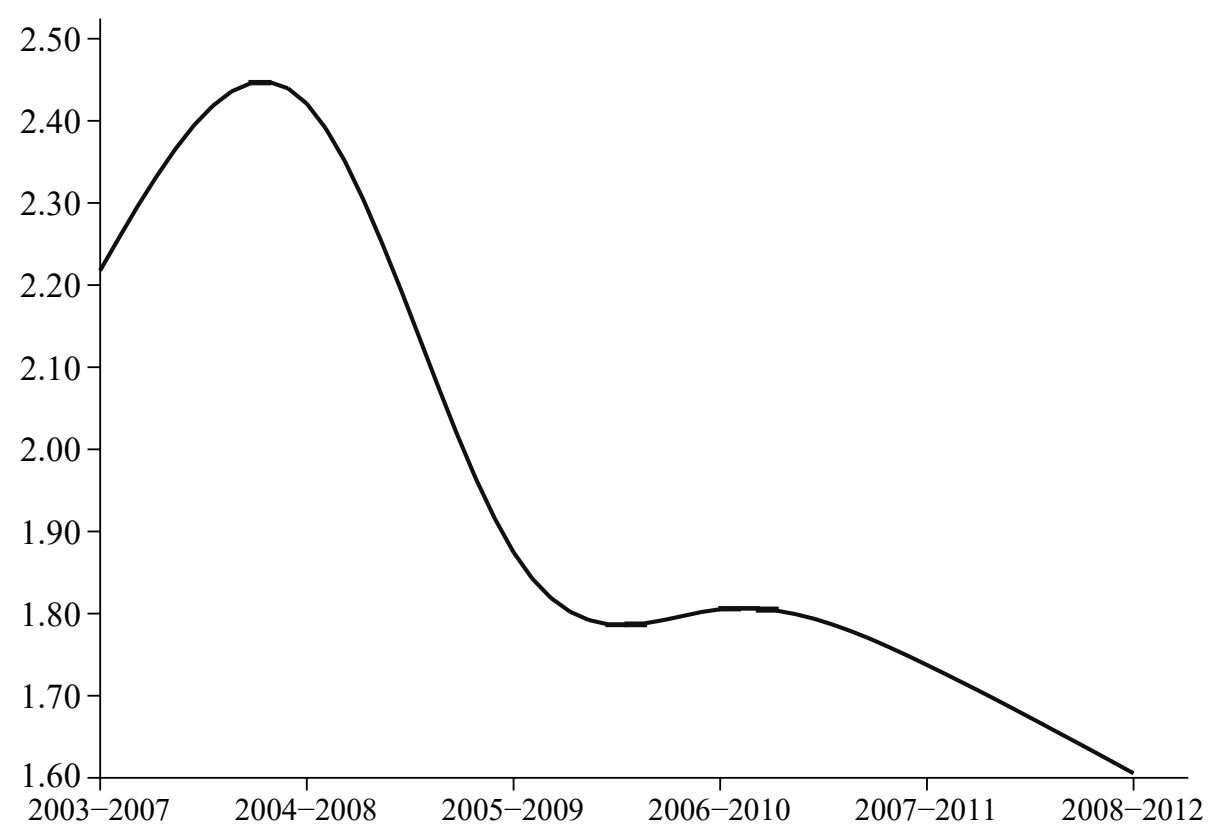

Figure A.2 The information content of cash flow

The figure plots estimates of $q$-cash flow sensitivity using 5-year rolling regressions for all firms (All), unbalanced sample (Unbalanced) and balanced sample (Balanced) over the sample period. The sample consists of listed non-utility and nonfinancial firms from Ivory Coast (CIV), Egypt (EGY), Ghana (GHA), Kenya (KEN), Morocco (MAR), Nigeria (NGA), South Africa (ZAF), Tunisia (TUN) and Zambia (ZMB) drawn from Datastream over the period from 2003 to 2012. All other variables used are defined in Table 1 , and are winsorised at the lower and upper one percentiles. 